\title{
PROTECTING THE TREASURE: AN ASSESSMENT OF STATE COURT RULES AND POLICIES FOR ACCESS TO ONLINE CIVIL COURT RECORDS
}

\author{
D.R. Jones*
}

\section{ABSTRACT}

State courts throughout the United States are rapidly implementing e-filing for civil court documents. Public access to these online records furthers the longstanding common law right of citizens to review court documents. At the same time, online access exposes a wealth of personal information contained in such records. During the last decade state courts struggled to develop and implement rules and policies for public access as courts anticipated a transition from print to electronic records. As e-filing becomes more prevalent, state courts must consider whether current rules and policies regarding public access to electronic court records provide adequate privacy protection.

This Article discusses the ongoing development of court rules and policies for public access to electronic court records. It assesses common approaches for providing and limiting access and determines that these approaches do not adequately address privacy concerns. Furthermore, this Article recommends that courts adopt the alternative approach of the Florida courts, which seeks to minimize the inclusion of personal information in court documents. In sum, courts must rethink the nature and purpose of court filings and how the content of those filings furthers the resolution of disputes.

TABLE OF CONTENTS

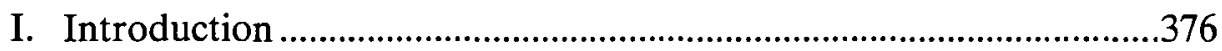

II. Public Access to Court Records-A Common Law Right ...............379

III. Development of State Court Policies on Public Electronic Access

IV. Current Approaches and Ongoing Challenges....................................389

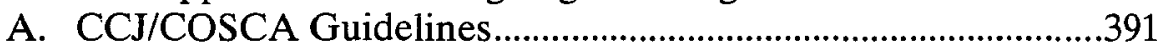

B. Assessing Current Approaches ......................................................393

1. Problems with Limited-Access Approaches ..........................394 Law. 


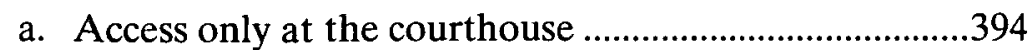

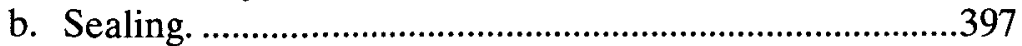

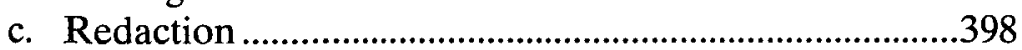

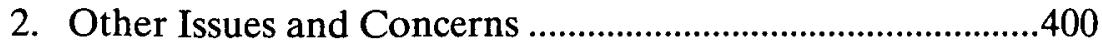

a. Implementation planning: Montana's experience.........400

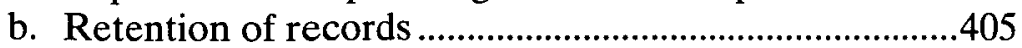

c. Accuracy problems and dossier creation........................409

d. Loss of context...................................................................411

V. Another Approach-A Fundamental Shift: Florida's Experience

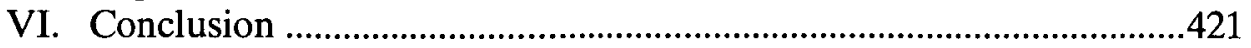

These Records, for that they contain great and hidden Treasure, are faithfully and safely kept (as they well deserve) in the King's Treasury. And yet not so kept but that any Subject may for his necessary Use and Benefit have Access thereunto, which was the ancient Law of England, and so is declared by an Act of Parliament....

Lord Coke ${ }^{1}$

\section{INTRODUCTION}

The United States has a long tradition of allowing public access to court records. One major underlying reason for allowing such access is to provide public review of judicial action. Court records, however, contain private and personal information about parties to lawsuits as well as information about witnesses and other nonparties. These records can include names of children and spouses, social security numbers, addresses, financial information, and descriptions of alleged wrongdoings. Concern regarding access to these records and the wealth of information contained within them was minimal until the late twentieth century because the documents were difficult to access, and thus cloaked in "practical obscurity." 2 To obtain records for a particular state court case, an interested person had to go to a courthouse and navigate the system of obtaining access to the files, reviewing the documents, and copying the

1. 3 EDWARD COKE, REPORTS OF EDWARD COKE, at A3-A4 (n.p., E. \& R. Nutt \& R. Gosling 1727). Lord Coke was referring to 46 Edw. 3 (1372) (Eng.) (An English translation of the statute is in Caddy v. Barlow, (1827) 31 Rev. Rep. 325 (K.B.) 328 n.; 1 Man. \& Ry. 275, 279 n.a.).

2. See infra text accompanying notes 27-32. 
desired materials. Only a small number of people were willing to undertake this task.

At the end of the twentieth century the availability of computers with large storage capacity provided courts the opportunity to digitize court records and even require the filing of electronic records. Maintaining court records in electronic form facilitated records management. In addition, courts could provide widespread public access to court records. Digitization has provided an alternative to the difficult process of manually accessing print records. Some states even have constitutional and statutory provisions mandating public access to records, and expanding access through the Internet promotes this interest.

The practical obscurity of court records evaporates as a consequence of public online access. Once a court allows online access and makes records available, anyone with a computer can search and quickly access the records. As online availability increases, so do concerns about the exposure of private, personal information. Whatever "great and hidden treasure" Lord Coke thought was in the records of the seventeenth century, the great treasure held in twenty-first century records is the wealth of personal data contained therein. Access to this information provides riches to those who wish to remove information about a person from its court context and market the information as part of an aggregated package. ${ }^{3}$ It also serves the interests of people who wish to engage in nefarious actions such as identity theft and stalking. There is a serious need for rules and procedures that address the tension between public access and protection of personal data and information.

In the first decade of the twenty-first century, the movement to provide online access to court records grew. As state courts considered the best approach to handling online court records, national organizations produced and recommended guidelines for providing public access to online records. At the same time, the actual availability of online court records was limited or nonexistent. ${ }^{4}$ In the second decade of the twenty-

3. As one scholar noted, "Information belies the adage about sewing silk purses out of sows' ears, for out of worthless bits [of] information we may sew assemblages that are rich in value." Helen Nissenbaum, Protecting Privacy in an Information Age: The Problem of Privacy in Public, 17 L. \& PHIL. 559, 587 (1998).

4. See David Schanker, E-Filing in State Appellate Courts: An Appraisal, in FutURE TRENDS IN STATE COURTS 2010, at 137, 137 (Carol R. Flango et al. eds., 2010), available at http://contentdm.ncsconline.org/cgi-bin/showfile.exe?CISOROOT= /ctadmin\&CISOPTR=1605; Lynne Marek, Patchwork E-Filing Frustrates Lawyers, NAT'L L.J. (Feb. 26, 2008), http://www.law.com/jsp/lawtechnologynews/PubArticleLTN 
first century, courts are still developing, revising, and implementing policies and rules for providing public access to electronic court records. Implementation of e-filing is rising as courts, faced with limited budgets and lack of space, consider alternatives to maintaining print records. ${ }^{5}$ Thus, there is a continuing need to evaluate approaches to providing public access to online court records.

This Article discusses the ongoing development of state court policies and rules governing public access to electronic civil court records. ${ }^{6}$ More importantly, it assesses whether current policies and rules are effective in balancing public access rights with protection of personal information. Part II discusses the common law roots of the public's right to access court records. Part III discusses the early development of state court policies and the movement of states toward the use of electronic records systems in the 1990s. It also describes two important reports from the National Center for State Courts regarding electronic access. Part IV offers an assessment of current approaches regarding access to court documents, relying on a recognized set of national guidelines that reflect common approaches state courts have adopted. This Part examines and evaluates some suggested alternatives to providing full access to electronic records. This Part also discusses several unresolved issues regarding publicly accessible electronic court records. Part V discusses the comprehensive approach that Florida adopted to address the challenge of protecting privacy while providing public access to online court records. This approach involved rethinking the nature and purpose of court records and the reasons for including

.jsp?id=900005504188\&slreturn=1.

5. See Laura Ruane, U.S. Courts Pare Down on Paper, Go Digital, USA TODAY (Feb. 21, 2012), http://www.usatoday.com/news/nation/story/2012-02-07/courtsdigital-paper/53182540/1.

6. This Article does not discuss the development of rules governing criminal records. State courts have been developing rules governing criminal records separately from rules governing civil records. For discussion of the protection of information in electronic criminal records, see Rebecca Hulse, Privacy and Domestic Violence in Court, 16 WM. \& MARY J. WOMEN \& L. 237 (2010); Caren Myers Morrison, Privacy, Accountability, and the Cooperating Defendant: Towards a New Role for Internet Access to Court Records, 62 VAND. L. REV. 921 (2009); John Losinger, Comment, Electronic Access to Court Records: Shifting the Privacy Burden Away from Witnesses and Victims, 36 U. BALT. L. REv. 419 (2007). This Article also does not address protection of personal information in appellate court opinions. For a discussion of that subject, see Joel M. Schumm, No Names, Please: The Virtual Victimization of Children, Crime Victims, the Mentally Ill, and Others in Appellate Court Opinions, 42 GA. L. REV. 471 (2008). 
personal information in such documents. The result was extensive changes in the nature of court filings and rules governing those filings. Part VI concludes that courts should adopt the Florida approach as an appropriate means to balance the competing interests of providing public access to court records and protecting personal information.

\section{PUBLIC ACCESS TO COURT RECORDS-A COMMON LAW RIGHT}

The basis for providing public access to court records lies in a longstanding common law right. In his Treatise on the Law of Evidence, Simon Greenleaf states that "it has been admitted, from a very early period, that the inspection and exemplification of the records of the king's courts is the common right of the subject." In discussing a party's right to a copy of a record, in Browne v. Cumming, the King's Bench cites Lord Coke's statement that the "ancient law of England" allowed subjects to access court records. ${ }^{8}$ American courts recognize this common law right. ${ }^{9}$ The U.S. Supreme Court, in Nixon v. Warner Communications, Inc., recognized that members of the public have a right to inspect judicial records, even if they do not have "a proprietary interest in the document or ... a need for it as evidence in a lawsuit." 10 In writing for the majority, Justice Powell recognized the English heritage of this right. ${ }^{11}$

Some federal courts have linked the right of access to court records to

7. 1 Simon GreEnleaf, A Treatise on the LAw of EVIDENCE $\$ 471$ (16th ed. 1899) (emphasis omitted). In his discussion, Greenleaf refers to a 1372 English statute, 46 Edw. 3 (1372) (Eng.). Id. For discussion of the common law right of public access to judicial records, see Note, The Common Law Right to Inspect and Copy Judicial Records: In Camera or on Camera, 16 GA. L. REv. 659, 660-66 (1982) (discussing English common law); see also 23 R.C.L. $\$ 12$ (1919), available at http://books.google.com/books?id=RNkUAAAAYAAJ\&printsec=frontcover $\# v=$ onep age $\& \mathrm{q} \& \mathrm{f}=$ false .

8. Browne v. Cumming, (1829) 109 Eng. Rep. 377 (K.B.) 378; 5 Man. \& Ry. 118 (quoting 3 COKE, supra note 1 ).

9. See Stewart Wilder, Comment, All Courts Shall Be Open: The Public's Right to View Judicial Proceedings and Records, 52 TEMP. L.Q. 311, 337-39 (1979) (discussing American common law).

10. Nixon v. Warner Commc'ns, Inc., 435 U.S. 589, 597 (1978). This case addresses whether television networks and others could have copies of recorded tapes used as evidence in a criminal trial against former advisors of President Richard Nixon. Id. at 591. The Court ultimately based its decision to deny access to the tapes on a federal statute governing access to presidential materials. Id. at 603. For more information on the Nixon case in the context of access to judicial records, see United States v. Criden, 648 F.2d 814, 819-20 (3d Cir. 1981).

11. Id. Justice Powell cited Browne, (1829) 109 Eng. Rep. 377. 
the public's right to attend trial proceedings. In United States v. Mitchell, the Federal Court of Appeals for the District of Columbia compared the policies supporting a right to access court records to those supporting the right to a public trial. ${ }^{12}$ The Third Circuit Court of Appeals, in United States v. Criden, observed that the policies supporting public access to records identified in Nixon were similar to those identified in Richmond Newspapers, Inc. $v$. Virginia ${ }^{13}$ - to support public access to a criminal trial. ${ }^{14}$ In Publicker Industries, Inc. v. Cohen, the Third Circuit Court of Appeals observed that the rights of access to court records and access to court proceedings are linked and applicable to both civil and criminal trials. ${ }^{15}$ The court in Cohen noted that "[t]he existence of a common law right of access to judicial proceedings and to inspect judicial records is beyond dispute."16 The policy support for open access to court records and judicial proceedings lies in the need to inform citizens of the workings of the judicial process and to allow them to monitor the actions of the judiciary. ${ }^{17}$

12. United States v. Mitchell, 551 F.2d 1252, 1257-58 (D.C. Cir. 1976), rev'd on other grounds sub nom. Nixon, 435 U.S. 589.

13. Richmond Newspapers, Inc. v. Virginia, 448 U.S. 555 (1980). The opinion in Richmond contains an extensive discussion of the history of open access to criminal court proceedings. See id. at 564-73.

14. Criden, 648 F.2d at 820 . In Richmond, the Supreme Court held that the First Amendment guarantees public access to a criminal trial. Richmond, 448 U.S. at 580. The Supreme Court did not address the public's right to attend civil trials, but noted that "historically both civil and criminal trials have been presumptively open." $I d$. at $580 \mathrm{n.17}$. The Third Circuit in Criden did not consider applicability of the First Amendment, but determined that the same policy analysis should apply to the common law right of access to records. Criden, 648 F.2d at 820 . The Supreme Court has not yet recognized a First Amendment right to access trial records or to attend civil trials. For a discussion of the application of the First Amendment to the access of court records by the lower federal courts, see Ronald. D. May, Recent Development, Public Access to Civil Court Records: A Common Law Approach, 39 VAND. L. REV. 1465 (1986).

15. Publicker Indus., Inc. v. Cohen, 733 F.2d 1059, 1066-67 (3d Cir. 1984) ("[T] he public's right of access to civil trials and records is as well established as that of criminal proceedings and records . . . ."). The Third Circuit Court of Appeals referenced Gannett Co. v. DePasquale, in which the Supreme Court discussed public access to civil and criminal trials. See id.; see also Gannett Co. v. DePasquale, 443 U.S. 368, 386 n.15 (1979). The Supreme Court in Gannett observed that many English commentators had described open proceedings in both criminal and civil proceedings. Gannett Co., 443 U.S. at 386 n.15. The Supreme Court referenced, among others, Lord Coke and Sir John Hawles. Id.

16. Cohen, 733 F.2d at 1066 (citing Criden, 648 F.2d at 819).

17. See Cohen, 733 F.2d at 1070 ("Public access to civil trials also provides information leading to a better understanding of the operation of government as well as confidence in and respect for our judicial system."); In re Cont'l Ill. Sec. Litig., 732 
The link between access to court records and access to judicial proceedings emanates from the notion that access to court records informs those citizens unable to attend court proceedings. In United States v. Antar, the Third Circuit Court of Appeals observed that:

At the heart of the Supreme Court's right of access analysis is the conviction that the public should have access to information... True public access to a proceeding means access to knowledge of what occurred there.

Access to the documentation of an open proceeding, then, facilitates the openness of the proceeding itself by assuring the broadest dissemination. It would be an odd result indeed were we to declare that our courtrooms must be open, but that transcripts of the proceedings occurring there may be closed, for what exists of the right of access if it extends only to those who can squeeze through the door? ${ }^{18}$

While court records are subject to public access, an individual still has a privacy interest in information about that person contained in the records. Courts must balance the established right of citizens to access records with the privacy rights of individuals. For example, in United States Department of Justice v. Reporters Committee for Freedom of the Press, the Supreme Court determined that information contained in a governmentcompiled "rap sheet" was not accessible, even though the information

F.2d 1302, 1308 (7th Cir. 1984) (stating that policies of open access to courts and documents "relate to the public's right to monitor the functioning of our courts, thereby insuring quality, honesty and respect for our legal system" (footnote omitted) (citations omitted)); Mitchell, 551 F.2d at 1258 (opining that right of access to judicial records is fundamental to a democratic state); Cowley v. Pulsifer, 137 Mass. 392, 394 (1884) (Justice Oliver Wendell Holmes wrote that public access to court proceedings is important "because it is of the highest moment that those who administer justice should always act under the sense of public responsibility, and that every citizen should be able to satisfy himself with his own eyes as to the mode in which a public duty is performed."); see also Gregory M. Silverman, Rise of the Machines: Justice Information Systems and the Question of Public Access to Court Records over the Internet, 79 WASH. L. REV. 175, 208-09 (2004) (arguing that access to court records "promotes public trust and confidence in the judiciary").

18. United States v. Antar, 38 F.3d 1348, 1360 (3d Cir. 1994) (footnotes omitted). In Antar, the court recognized the public's right to access jury voir dire transcripts. See id. at 1361. 
came from public records. ${ }^{19}$ The Court noted that compilations of information can affect personal privacy far more than scattered "bits of information." 20 In Reporters Committee, a reporter and a journalists' association filed a Freedom of Information Act (FOIA) request ${ }^{21}$ for an FBI rap sheet of an individual. ${ }^{22}$ The rap sheet was a compilation of information gathered from various public records. ${ }^{23}$ The requesters argued that since the information in the rap sheet came from records that were publicly available, they should be able to obtain a copy of the rap sheet.24 The Department of Justice denied access to the rap sheet, relying on an exemption in FOIA that protected law enforcement records if providing the records "could reasonably be expected to constitute an unwarranted invasion of personal privacy." 25 In the lawsuit that followed, the district court granted the Department's summary judgment motion, and the Federal Court of Appeals for the District of Columbia reversed that decision. ${ }^{26}$

On appeal to the Supreme Court, the Department argued that the "practical obscurity of widely scattered ... public records" that were the source of the rap sheet shielded the individual's privacy. ${ }^{27}$ In the Department's view, the subject of the rap sheet had a protectable privacy interest in the obscurity of these records. ${ }^{28}$ Compiling information from these records destroyed that protection. ${ }^{29}$ Agreeing with the Department of Justice, the Supreme Court distinguished access to the compiled rap sheet from access to the public records that were the source of the information in the rap sheet. ${ }^{30}$ The Court noted that "there is a vast difference between the public records that might be found after a diligent search of courthouse

19. See U.S. Dep't of Justice v. Reporters Comm. for Freedom of the Press, 489 U.S. $749,764,780$ (1989).

20. Id. at 765 .

21. See 5 U.S.C. $\S 552(2006)$.

22. Reporters Comm., 489 U.S. at 757.

23. See id.

24. See id.

25. Id. at 756; see also 5 U.S.C. $\$ 552(\mathrm{~b})(7)(\mathrm{C})$ (providing the exemption).

26. Reporters Comm., 489 U.S. at 757, 759.

27. Reply Brief for the Petitioners at 2, Reporters Comm., 489 U.S. 749 (1989) (No. 87-1379), 1988 WL 1026019 at *2 (internal quotation marks omitted); see also Petition for Writ of Certiorari at 5, Reporters Comm., 489 U.S. 749 (1989) (No. 87 1379), 1989 WL 1174467 at *5.

28. See Petition for Writ of Certiorari, supra note 27, at 5 .

29. See Reply Brief for the Petitioners, supra note 27, at 6.

30. Reporters Comm., 489 U.S. at 764. 
files, county archives, and local police stations throughout the country and a computerized summary located in a single clearinghouse of information." ${ }^{31}$ While this case interpreted and applied FOIA with regard to a government agency document, it has become authority for the notion that the "practical obscurity" of scattered and difficult-to-access public records, including court records, provides a measure of privacy protection for the information in the records. This case affirmed that while public records are open, the individual does "not necessarily forfeit a privacy interest in matters made part of the record." 32 Courts must balance individual privacy interests with the common law right to access records.

\section{DeVElopment of STATE Court Policies on Public Electronic ACCESS}

State courts have long recognized the public's right of access to court records and allowed physical access to paper records housed in individual courthouses..$^{33}$ Until the late twentieth century, there was little concern for protection of personal information in the records or the need to balance an individual's privacy right against the right of public access. ${ }^{34}$ The challenges anyone seeking state court records faced in obtaining access at a courthouse effectively limited widespread use of the records and dissemination of the information they contained. ${ }^{35}$ Accessing any court record required physically going to a courthouse, which might require travel to another county or state. Once at the courthouse, the record requestor had to contend with everything from parking and limited courthouse hours to navigating the maze of procedures for requesting, receiving, and copying documents. ${ }^{36}$ These challenges effectively provided

31. Id.

32. Id. at 763 n.15.

33. Paul H. Anderson, Future Trends in Public Access: Court Information, Privacy, and Technology, in FUTURE TRENDS IN STATE COURTS 2011, at 10 (Carol R. Flango et al. eds., 2011).

34. Compare Cowley v. Pulsifer, 137 Mass. 392, 394 (1884) (holding trials "should take place under the public eye" so citizens know justice was served), with Gannett Co. v. DePasquale, 443 U.S. 368, 370-71 (1979) (announcing a balancing of public access rights with interest in closed proceeding to ensure a fair trial).

35. Anderson, supra note 33, at 11.

36. See Kevin P. Kilpatrick, Nat'l Ctr. for State Courts, The Electronic Handshake: Public AcCess to Court Databases 2 (1995), available at http://contentdm.ncsconline.org/cgi-bin/showfile.exe?CISOROOT=/accessfair \&CISOPTR=224; Silverman, supra note 17, at 194-95 (discussing the challenges and process of accessing paper court records at a courthouse). 
the practical obscurity that the Supreme Court discussed in Reporters Committee. ${ }^{37}$

In the late twentieth century, courts began to consider the use of technology to manage documents and improve court service to the public. ${ }^{38}$ At the same time, courts considered how to address issues regarding the exposure of private information in online records. In 1995, the National Center for State Courts (NCSC) published two companion reports to provide guidance to courts considering electronic access: ${ }^{39}$ the Kilpatrick Report $^{40}$ and the Jennen Report. ${ }^{41}$ The Kilpatrick Report examined electronic access to court information and records ${ }^{42}$ and discussed issues critical to the implementation of an electronic access system. ${ }^{43}$ It also offered guidance on development and implementation. ${ }^{44}$ This report focused on systems that allowed remote access rather than courthouse access at public terminals. ${ }^{45}$ It identified the reasons why courts with remote access systems implemented such systems: ${ }^{46}$ remote access through personal computers could (1) accommodate the growth in case filings, (2) improve service to the public, and (3) reduce time demands upon public

37. See supra text accompanying notes $27-32$.

38. See KilPatrick, supra note 36 , at 1-2. Providing physical access to records also required extensive time and effort of court personnel, so courts sought ways to limit the costs associated with this work. See id.

39. See id. at 4.

40. KILPATRICK, supra note 36.

41. Susan M. Jennen, Nat'l CTr. For State Courts, Privacy and Public ACCESS to Electronic Court Information: A Guide to Policy DECISIONS FOR STATE COURTS (1995), available at http://contentdm.ncsconline.org/cgibin/showfile.exe?CISOROOT=/accessfair \&CISOPTR $=222$.

42. See KILPATRICK, supra note 36, at 3. Research focused on data and information gathered from surveys of courts, state judicial information system directors, and system users, as well as data from on-site visits to some courts. See id. at 5, 9; see also J. DOUglas WALKER, NAT'L CTR. FOR STATE COURTS, THE Challenging Voyage to Statewide Court Automation: A National ASSESSMENT 3 (1994), available at http://contentdm.ncsconline.org/cgi-bin/showfile .exe?CISOROOT $=/$ tech \&CISOPTR $=12$ (discussing issues "involved in managing the process of statewide automation," and including a detailed fifty-state survey of trial court automation).

43. KILPATRICK, supra note 36, at 45. At the time of the report, there were very few courts that had actually implemented an electronic public access system that would support the filing of case documents. See id. at 35.

44. Id. at 55-62.

45. Id. at 34. Access was through dial-up Internet. Id.

46. Id. at 33 . 
researchers and court staff. ${ }^{47}$

The Kilpatrick Report referred to the Jennen Report to address the issue of how to develop policies for access to records in a court system. ${ }^{48}$ The Jennen Report provided an extensive discussion of the conflicting privacy and open access concerns inherent in determining electronic record access policies..$^{49}$ The report determined that existing law was not adequate to guide state courts in developing policies, and courts thus needed to examine other factors such as a court's operational issues. ${ }^{50}$ The Jennen Report did not suggest specific language for policies, but rather, it offered extensive guidelines for courts to consider when developing policies. ${ }^{51}$

When discussing the reasons for providing electronic access to court records, the Kilpatrick Report and the Jennen Report both referenced the 1990 Trial Court Performance Standards.52 The Jennen Report also referenced these standards when discussing the development of access policies..$^{53}$ The purpose of the Trial Court Performance Standards was to support court reform and accountability, and the standards were focused on measuring courts' performance (outcomes) rather than on resources and processes (inputs)..$^{54}$ The Kilpatrick Report noted the importance of public access identified in Performance Standard 1 (Access to Justice). ${ }^{55}$

47.

See id. at 1-2; see also J. DOUGlas WALKER, NAT'L CTR. FOR STATE COURTS, ELECTRONIC COURT DOCUMENTS: AN ASSESSMENT OF JUDICIAL ELECTRONIC DOCUMENT AND DATA INTERCHANGE TECHNOLOGY 15 (1999), available at http://contentdm.ncsconline.org/cgi-bin/showfile.exe?CISOROOT $=/$ tech\&CISOPTR $=5$ ("With the nearly continuous rise in volume and complexity of the paperwork involved in the judicial process ... technology and electronic communications could offer a better alternative to the flood of paper forms and documents."). The Walker Report discusses the results of a study in Shawnee County Court in Kansas that compared the time necessary to process 100 documents manually with the time to process them electronically. Id. at 18-19. The study showed that it took 9.75 hours to process the documents in paper form and 8.8 minutes electronically. Id.

48. KILPATRICK, supra note 36, at 56.

49. See JENNEN, supra note 41 , at 5-23.

50. See id. at 39, 43-44.

51. Id. at $39-46$.

52. Id. at 26; KILPATRICK, supra note 36, at 1 ; see COMM'N ON TRIAL COURT Performance Standards, Nat'l CTr. For State Courts, Trial Court PERFORMANCE STANDARDS WITH COMMENTARY (1990) [hereinafter 1990 TRIAL COURT PERFORMANCE STANDARDS], available at http://contentdm.ncsconline.org/cgibin/showfile.exe?CISOROOT $=/$ ctadmin $\&$ CISOPTR $=335$.

53. See JENNEN, supra note 41, at 26, 39-40.

54. 1990 TRIAL COURT PERFORMANCE STANDARDS, supra note 52, at 1.

55. KILPATRICK, supra note 36 , at 2. 
Performance Standard 1 recognized the "importance of the relationship between [access to] public records and access to justice" and the need to serve "persons seeking information from public records." 56 The Jennen Report referenced the 1990 Trial Court Performance Standards to support broad access to records. ${ }^{57}$ The Jennen Report noted Performance Standard 4.2 , which states that a trial court should "responsibly seek the resources needed to meet its judicial responsibilities, use those resources prudently, ... and account for their use." 58 The Jennen Report suggested that a court desiring to maintain a "high degree of accountability" under Performance Standard 4.2 could adopt a broad policy that "all records and court data should be open for public review and access." 59 The Jennen Report, however, also referenced the Trial Court Performance Standards to suggest exceptions to allowing open access to records. ${ }^{60} \mathrm{~A}$ court could make "legitimate exceptions" based upon "a clear showing of countervailing public policy or public or individual harm." Performance Standard on Public Trust and Confidence, ${ }^{62}$ the Jennen Report questioned "whether the release of certain electronic data" would violate the public's trust and confidence in the court system. ${ }^{63}$ If citizens perceive that the courts will not protect personal information from dissemination, they may become reluctant to use the courts. ${ }^{64}$

This discussion in the Jennen Report illustrates a conflict in court goals in providing public access to electronic court records. On the one hand, providing electronic access improves public service by making access to court records easier and cheaper. Electronic access, however, negates the obscurity of the documents, making private information more available and raising questions about the court's concern for individual citizens. As

56. 1990 Trial Court PERFormanCE STANDARDS, supra note 52, at 7.

57. See JENNEN, supra note 41, at 26.

58. Id. (quoting 1990 TRIAL COURT PERFormance STANDARDS, supra note 52 , at 19) (internal quotation marks omitted) (footnote omitted).

59. Id.

60. Id.

61. Id.

62. 1990 Trial CoURT PERFormance STANDARDS, supra note 52, at 20.

63. JENNEN, supra note 41, at 20.

64. Id. The Jennen Report references Performance Standard 5.2, which provides that " $[\mathrm{t}]$ he public has trust and confidence that the basic trial court functions are conducted expeditiously and fairly and that its decisions have integrity." Id. (quoting 1990 Trial COURT PERFormance STANDARDS, supra note 52, at 22) (internal quotation marks omitted) (footnote omitted). The Jennen Report does not acknowledge that this standard could also support a broad access policy. See id. 
noted in the Kilpatrick Report, many of the system users surveyed expressed an interest in obtaining detailed data from court records. ${ }^{65}$ This same interest raises concerns about the use of personal information, for purposes perhaps unrelated to an interest in a court case. ${ }^{66}$

During the late 1990s and the early 2000s, courts began developing and adopting policies regarding public access to electronic court records for the reasons identified in the Kilpatrick and Jennen Reports. ${ }^{67}$ State courts focused on developing policies even though few courts had online filing systems and electronic records. ${ }^{68}$ This process stood in stark contrast to the experience in the federal courts, which adopted a uniform policy and an online filing system. ${ }^{69}$

65. See KILPATRICK, supra note 36 , at 13, 37-38.

66. See Lynn E. Sudbeck, Placing Court Records Online: Balancing Judicial Accountability with Public Trust and Confidence: An Analysis of State Court Electronic Access Policies and a Proposal for South Dakota Court Records, 51 S.D. L. REV. 81, 99 n.64 (2006) (citing KILPATRICK, supra note 36, at 37-38).

67. See id. at $99 \mathrm{nn} .63-65$ (citing JENNEN, supra note 41; KILPATRICK, supra note 36 , at $35,37-38$ ).

68. See Peter W. Martin, Online Access to Court Records-From Documents to Data, Particulars to Patterns, 53 VILL. L. REV. 855, 872 (2008); see also Marek, supra note 4. For example, Vermont was one of the early states to adopt a policy on public access to electronic court records, but it did not adopt e-filing until much later. VT. R. GOVERNING DISSEMINATION OF ELECTRONIC CASE RECORDS 1 (stating effective date of June 1, 2002); VT. R. FOR ELECTRONIC FILING 1(a)(1) (noting that e-filing commenced between October 18, 2010, and January 25, 2011). The concept for the Vermont rules originated in a technology committee study, which the Vermont Supreme Court adopted in 1998. VT. COMM'N ON JUDICIAL OPERATION, FINAL REPORT TO THE LEGISLATURE 14 (2009). The court adopted the Rules Governing Dissemination of Electronic Case Records in 2002. VT. R. Governing DisSEMINATION OF ELECTRONIC CASE RECORDS 1. The Vermont state courts did not start implementing e-filing until October 2010. See VT. R. FOR ELECTRONIC FILING 1(a)(1); see also John A. Dooley III et al., E-filing is Coming, 36 VT. B.J., Summer 2010 , at 22.

69. See generally Martin, supra note 68, at 872-84 (discussing the federal system). The states have not followed the federal model; therefore, I will not discuss that system in detail. For researchers interested in the federal model, I provide a summary of the key decisions that underlie the federal system. The online vehicle for accessing federal court records is Public Access to Court Electronic Records (PACER). PACER, http://www.pacer.gov/ (last visited Jan. 9, 2013). In 1988 the Judicial Conference of the United States authorized electronic access for federal court records. JUDICIAL CONFERENCE OF THE U.S., REPORT OF THE PROCEEDINGS OF THE JUDICIAL CONFERENCE OF THE UNITED STATES 83 (1988), available at http://www.uscourts.gov/FederalCourts/JudicialConference/Proceedings/Proceedings.a spx?doc=/uscourts/FederalCourts/judconf/proceedings/1988-09.pdf; see Electronic 
With so many variations in state court structure, management, and funding, each state court system had to develop its own policies. ${ }^{70}$ Courts struggled with the conflicting goals of providing access and protecting

Public Access at 10, THE THIRD BRANCH (Sept. 2000), http://www.uscourts.gov/News TheThirdBranch/00-09-01/Electronic_Public_Access_at_10.aspx. In 1990, Congress authorized funding for the electronic system. Department of Commerce, Justice, and State, the Judiciary, and Related Agencies Appropriations Act, Pub. L. No. 101-515, 104 Stat. 2101 (1990). By 1999, users could access the system on the Internet. PACER Arrives on the Internet, THE THIRD BRANCH (July 1999), http://www.uscourts.gov/News TheThirdBranch/99-07-01/PACER_Arrives_On_the_Net.aspx. In 2001, the Judicial Conference adopted privacy policy recommendations. JUDICIAL CONFERENCE OF THE U.S., REPORT OF THE PROCEEDINGS OF THE JUDICIAL CONFERENCE OF THE UNITED STATES 48-50 (2001), available at http://www.uscourts.gov/FederalCourts/Judicial Conference/Proceedings/Proceedings.aspx?doc=/uscourts/FederalCourts/judconf/proce edings/2001-09.pdf. See generally Privacy Policy for Electronic Case Files, U.S. COURTS, http://www.uscourts.gov/RulesandPolicies/JudiciaryPrivacyPolicy.aspx (last visited Jan. 9, 2013) (detailing the history of the privacy policy for electronic filing of court documents). The Committee on Court Administration and Case Management, which recommended the policy, identified several reasons to provide public access to electronic court records. Judicial CONFERENCE COMM. ON COURT ADMIN. \& CASE Mgmt., Report on PRivacy and Public ACCESS to Electronic CASE Files (2006) [hereinafter JUDICIAL CONFERENCE COMMITTEE REPORT], available at http://www.uscourts.gov/RulesAndPolicies/JudiciaryPrivacyPolicy/FormerJudicialConf erencePrivacyPolicy2006.aspx. The reasons cited in support of e-filing include: attorneys in civil cases would have easy access to records in any federal court thus leveling the geographic playing field; clerks could better serve the bar and public; and re-sellers of data would have less incentive to copy paper files and provide electronic access for a charge. $I d$. The federal policy regarding electronic court records is now embodied in the Federal Rules of Civil Procedure after being adopted in 2007. See FED. R. BANKR. P. 9037; Fed. R. CiV. P. 5.2; FED. R. CRIM. P. 49.1. These were new rules that the Judicial Conference and the U.S. Supreme Court adopted to comply with the E-Government Act of 2002. E-Government Act of 2002, Pub. L. No. 107-347, $\S 205,116$ Stat. 2899, 2915 (2002); see also REPORT OF THE PROCEEDINGs OF THE JUDICIAL CONFERENCE OF THE UNITED STATES 32-33 (2006), available at http://www.uscourts.gov/federalcourts/judicialconference/proceedings/proceedings.aspx ?doc=/uscourts/federalcourts/judconf/proceedings/2006-09.pdf; Memorandum from Judge David F. Levi to Honorable John G. Roberts 1 (Nov. 1, 2006), available at http://www.uscourts.gov/uscourts/RulesAndPolicies/rules/supct1106/summary_propose d_amend.pdf. After adoption of these rules, the Judicial Conference limited its policy to those portions that remain in effect apart from the rules. REPORT OF THE ProceEdings of THE Judicial CONFERENCE OF THE UNITED STATES 7-8 (2008), available at http://www.uscourts.gov/FederalCourts/JudicialConference/Proceedings /Proceedings.aspx?doc=/uscourts/FederalCourts/judconf/proceedings/2008-03.pdf; see also Judicial CONFERENCE Policy ON PRIVACY AND PUblic ACCESS To EleCtronic CASE FILES (Mar. 2008), available at http://www.uscourts.gov/RulesAndPolicies /JudiciaryPrivacyPolicy/March2008RevisedPolicy.aspx.

70. See WALKER, supra note 47 , at 17-18. 
individuals' personal information. ${ }^{11}$ Addressing these conflicts has inevitably led to a variation in court policies on electronic access to court records. ${ }^{72}$ Two approaches to providing access to court records have prominently emerged: the "public-is-public" approach and the "practicalobscurity" approach..$^{73}$ The public-is-public approach views all records the same, regardless of format or location..$^{74}$ The focus of any limitation of access is on the type of information in the document and whether it should be public. ${ }^{75}$ Any records and information available at a courthouse are also available online under this approach. ${ }^{76}$ Likewise, any restriction on access to sensitive information in a document would apply to records in paper and electronic format. ${ }^{77}$ The practical-obscurity approach, however, focuses on concerns regarding exposure of information in electronic documents that are available online. ${ }^{78}$ Courts following this approach provide access to print records at the courthouse and, perhaps, electronic access at kiosks in the courthouse, but they provide no electronic access otherwise. ${ }^{79}$ Those advocating this approach are sensitive to the danger inherent in the widespread availability of online records ${ }^{80} \mathrm{By}$ limiting access to records to physical access, there is greater protection of this information. ${ }^{81}$ Variations of this approach limit remote access to certain types of users, such as judges, court personnel, litigants, and counsel.$^{82}$ The public might have no remote access or only access to documents not likely to contain personal information. ${ }^{83}$

\section{CURRENT APPROACHES AND ONGOING CHALLENGES}

The Jennen Report predicted that "the transition from paper to electronic records [would] extend over many years and [would] proceed at

71. See OfFICE of Judges Programs, Admin. OfFice of THE U.S. Courts, PRIVACY AND ACCESS TO Electronic CASE Files IN THE Federal Courts 6-7 (1999), available at http://purl.access.gpo.gov/GPO/LPS12879.

72. See id. at 7.

73. See id.

74. See id.

75. See id. at 7,9 .

76. See id. at 1,6 .

77. $\quad I d$. at 7,9 .

78. $\quad I d$. at 7.

79. See generally id.

80. Id.

81. See id.

82. Id. at 10.

83. See id. 
different rates for different courts." 84 This prediction was certainly accurate. In the second decade of the twenty-first century, courts continue to develop, revise, and implement policies on public access to electronic records..$^{85}$ State courts are also implementing e-filing. ${ }^{86}$ With shrinking budgets, courts are finding electronic records attractive and so this movement has accelerated. ${ }^{87}$ Many state courts have discussed e-filing for years ${ }^{88}$ and it is now taking hold while simultaneously facilitating creation of a less expensive vehicle for public access to online records. ${ }^{89}$

As more records actually go online through e-filing, it is increasingly important to address questions on how to provide access to court records..$^{90}$ Court policies on access should evolve as systems for records evolve. ${ }^{91}$ In this Part, I consider the issues that exist with current state approaches. State courts vary in their approaches to providing access to electronic court records, so I use representative guidelines. After I examine these guidelines in Part IV.A, I will discuss in Part IV.B the issues arising from the approaches that those guidelines suggest and the issues that those guidelines do not address or address only to a limited extent.

84. JENNEN, supra note 41, at 27.

85. See, e.g., infra Part V (discussing developments in Florida); see also REPORT OF THE ADVISORY COMMITTEE ON CIVIL PRACTICE TO THE CHIEF ADMINISTRATIVE JudGE OF THE COURTS OF THE STATE OF NEW YORK 32-33 (2011), available at http://nycourts.gov/ip/judiciaryslegislative/2011-CivilPractice-ADV-Report .pdf; Robert P. Deyling, Privacy and Public Access to the Courts in an Electronic World: Common Themes and Diverse Approaches to Policy Development, 2 REYNOLDS CT. \& MEDIA L.J. 5, 19-20 (2012) (discussing recent developments in New York, Montana, and Maryland).

86. See William Glaberson, Amid Stacks of Paper, 'E-Court' is Finally in Session, N.Y. TIMES, July 8, 2011, at A20, available at http://www.nytimes.com/2011/07 /08/nyregion/at-state-supreme-court-in-manhattan-visions-of-paperless-future.html ?pagewanted=all; Jim O'Hara, E-filing of Court Papers Now a Reality in Onondaga County Clerk's Office, SYRACUSE.COM, http://www.syracuse.com/news/index.ssf/2012 /03/e-filing_of_court_papers_now_a.html (last updated Mar. 29, 2012); Ruane, supra note 5 .

87. See Ruane, supra note 5 (stating that budget cuts have led court systems to digital filing, ultimately reducing costs).

88. See O'Hara, supra note 86 (stating that for approximately the past ten years Onondaga County Court in New York has been moving towards adopting an electronic filing system); Ruane, supra note 5 (noting that the digital migration of court record systems dates back more than twenty years).

89. Glaberson, supra note 86; O'Hara, supra note 86; Ruane, supra note 5.

90. JENNEN, supra note 41, at 27.

91. Id. 


\section{A. $C C J / C O S C A$ Guidelines}

To the extent state courts have followed any guidelines in developing policies for access to electronic court records, they have followed-or at least consulted-guidelines that the Conference of Chief Justices (CCJ) and the Conference of State Court Administrators (COSCA) adopted in 2002.92 These guidelines (the CCJ/COSCA Guidelines) were part of an extensive report (the CCJ/COSCA Report) that the National Center for State Courts and the Justice Management Institute published in 2002. ${ }^{93}$ The $\mathrm{CCJ} / \mathrm{COSCA}$ Guidelines remain the most comprehensive resource for developing access policies for court records, although there have been no updates to the guidelines since their original adoption in 2002.94 The guidelines reflect state court policies, including policies that some states have adopted without consulting the guidelines. ${ }^{95}$ Therefore, the $\mathrm{CCJ} / \mathrm{COSCA}$ Guidelines are not model policies, but rather, they serve as "a map of the policy-making terrain" 96 and a "starting point for drafting a

92. See Sudbeck, supra note 66, at 92-93 (providing an overview of the $\mathrm{CCJ} / \mathrm{COSCA}$ Guidelines and state utilization of such guidelines). The $\mathrm{CCJ}$ and COSCA Guidelines were each adopted on August 1, 2002. See Conference of Chief Justices Res. 33 (2002), available at http://ccj.ncsc.dni.us/AccessToJustice Resolutions /resol33PublicAccessCourtRecords.html; Conference of State Court Admin'rs Res. IV (2002), available at http://cosca.ncsc.dni.us/Resolutions/resolutionGuidelines4Policy DvlpmntStateCts.html.

93. Martha Wade Steketee \& Alan Carlson, Nat'l CTR. For State COURTS \& JUSTICE MGMT. INST., DEVELOPING $C C J / C O S C A$ GUIDELINES FOR PUBLIC ACCESS to COURT ReCORDS: A National ProjeCt to Assist STATE Courts at vi (2002), available at $\mathrm{http} / /$ contentdm.ncsconline.org/cgi-bin/showfile.exe?CISOROOT $=/$ accessfair $\&$ CISOPTR $=210$.

94. A follow-up report in 2005 made no changes to the existing guidelines. This report provided details and examples of language to use to educate litigants and the public, provided a more detailed discussion regarding the development of internal court policies and procedures for handling records, and provided discussion regarding access to family court records. Alan CaRLSON \& MARTHA WADE STEKETEE, NAT'L CTr. For State Courts \& Justice Mgmt. Inst., Public ACcess to Court RECORDS: IMPLEMENTING THE CCJ/COSCA GUIDELINES, FINAL PROJECT REPORT (2005), available at http://contentdm.ncsconline.org/cgi-bin/showfile.exe?CISOROOT= /accessfair \&CISOPTR $=196$.

95. Creators of the CCJ/COSCA Guidelines relied on existing policies of several states to develop the guidelines, including: Arizona, California, Colorado, Minnesota, Vermont, and Washington. Martha Wade Steketee \& Alan Carlson, Privacy and Public Access to Court Records: Public and Private Dimensions Create a Diverse Group of Collaborators, in 2002 REPORT ON TRENDS IN THE STATE COURTS 23, 24 (2002), available at http://contentdm.ncsconline.org/cgi-bin/showfile.exe ?CISOROOT $=/$ ctadmin $\&$ CISOPTR $=422$.

96. STEKETEE \& CARLSON, supra note 93, at 2. The advisory committee for 
policy"97 by suggesting appropriate language. 98 Accompanying each guideline is extensive commentary highlighting the reasons for the suggested language, possible alternatives, and issues the policymaker must address. ${ }^{99}$

A key purpose of the CCJ/COSCA Guidelines is "to provide maximum public accessibility to court records." 100 The CCJ/COSCA Guidelines are, therefore, applicable to "all court records, regardless of the physical form, the method of recording the information ... or the method of storage of the information."101 This broad applicability suggests a publicis-public approach. ${ }^{102}$ Underlying the CCJ/COSCA Guidelines, however, are public policy concerns that support a balanced approach to providing access. ${ }^{103}$ The commentary to the CCJ/COSCA Guidelines recognizes that there could be "sound reasons for restricting access" to records. ${ }^{104}$ Therefore, some sections of the guidelines provide for restrictions or even prohibitions on access to certain records. ${ }^{105}$

The CCJ/COSCA Guidelines cover many aspects of access to court records, but at the heart of the guidelines are the Section 4.0 provisions, which address both the scope and possible limitations on access. ${ }^{106}$ The

this project made an early determination not to offer a "model," but instead offer "guidelines." Steketee \& Carlson, supra note 95, at 24.

97. STEKETEE \& CARLSON, supra note 93, at 2. The CCJ/COSCA Guidelines are for statewide adoption or for local court adoption if there is not a state policy. Id. Commentary in the guidelines identifies additional necessary language if the state's judiciary adopts a statewide process. See id. at 24-25 (discussing whether a local court may adopt a more restrictive policy regarding access to online court documents).

98. See generally id.

99. Id. at 2. For example, the CCJ/COSCA Guidelines emphasize that in developing or refining policies, a state needs to consider its statutory and case law as well as existing records practices. $I d$.

$100 . \quad I d$. at 4.

101. Id. at 22.

102. See supra notes $72-75$ and accompanying text (discussing the public-ispublic approach).

103. STEKETEE \& CARLSON, supra note 93, at 4-5.

104. Id.

105. See id. at 45 (prohibiting access to information not accessible to the public pursuant to a court rule or federal or state case law).

106. See id. at 22-57. For example, Section 4.50 provides basic language for limiting remote access to certain types of records, with an option for a court to include a list of "information available only at a court facility." $I d$. at 39. Likewise, commentary to Section 4.60 notes that in many situations existing state or federal law may dictate restrictions on accessibility of certain kinds of information or types of records, and it 
guidelines create a presumption of openness; ${ }^{107}$ it is the method of access that the court should limit, not access to the document itself.108 The CCJ/COSCA Guidelines offer flexibility for developers of court rules and policies. For example, commentary to the guidelines offers alternative means of limiting access aside from providing access only at the courthouse. ${ }^{109}$ The guidelines thus provide both a public-is-public approach and variations of a limited-access approach.

\section{B. Assessing Current Approaches}

In Part IV.B.1, I discuss some problems with approaches the $\mathrm{CCJ} / \mathrm{COSCA}$ Guidelines suggest as alternatives to providing full electronic access to records. These approaches, such as limiting access to the courthouse for some records or information, reflect choices that some state courts have made to control access to personal information. In Part IV.B.2, I discuss critical issues the CCJ/COSCA Guidelines do not address or do not adequately address. Some of these issues arise from the transitional nature of the means by which courts maintain their records. As the Jennen Report notes: "The progressive transformation of the court record, from paper to electronic forms, complicates the process of developing coherent, consistent, and strategic policy about public access." 110 Courts reexamining existing policies or developing new policies should consider whether the approach they adopt will incorporate a means to address these issues on an ongoing basis.

This Part is not intended to provide an exhaustive discussion of these problems, many of which merit more detailed individual consideration. I highlight these issues simply to note their place in the conversation about the development of policies for access to court records. Current policy approaches, as reflected in the CCJ/COSCA Guidelines, fall short of adequately addressing these problems. There should be more consideration of the underlying purpose for which information became part of a court

offers examples of types of cases, documents, and information to which a state or individual court could restrict access. Id. at 39, 45-52.

107. Id. at 39.

108. Id.

109. Id. at 39-40. The commentary suggests that remote access could be only through a subscription service or only to one case at a time. Id. at 39 . The commentary also provides examples of types of records or information in records to which a court could restrict or prohibit online access. Id. at 40 . Examples of such records include: medical records, family law proceedings, and photographs of victims. Id.

110. JENNEN, supra note 41, at 27. 
record and a movement away from manipulating information in records or providing access only at the physical location of the information. In Part V, I discuss the approach of one state that has gone beyond managing information in court records to redefining the nature and purpose of the records themselves.

\section{1. $\quad$ Problems with Limited-Access Approaches}

a. Access only at the courthouse. For hundreds of years, the public could access court records only at the courthouse. The practical obscurity provided through this arrangement still offers appeal. The CCJ/COSCA Guidelines acknowledge that courts might decide to adopt policies that would treat records differently by restricting the manner of access. ${ }^{111}$ Under one suggested guideline, courts could provide access to certain identified information only at a court facility. ${ }^{112}$ The provided information could be in paper format or in electronic format accessible at a courthouse kiosk or terminal. ${ }^{113}$ Limiting access to the courthouse, however, perpetuates inequality, which is contrary to a key purpose of providing online access. Moreover, limiting access does not stop enterprising data-gatherers, who, through the use of readily available technology, can circumvent any protection that limiting access to the courthouse otherwise offers.

Allowing access to the same records online as are available at the courthouse provides the broadest access to the public. Just as few people can attend court proceedings in person and hear evidence, ${ }^{114}$ few can (realistically) go to the courthouse and obtain records. If courts keep some information at the courthouse, whether in paper or electronic format, those with the most resources will be able to access it. Adopting a public-is-public approach can level the geographic playing field for those who are not in the same jurisdiction as the records or who cannot easily visit a courthouse. ${ }^{115}$

111. STEKETEE \& CARLSON, supra note 93, at 39.

112. Id.

113. Id.

114. In one of the cases regarding the Nixon tapes litigation, the U.S. Court of Appeals for the District of Columbia noted that "the right of inspection serves to promote equality by providing those who were and those who were not able to gain entry to Judge Sirica's cramped courtroom the same opportunity to hear the White House tapes." United States v. Mitchell, 551 F.2d 1252, 1258 (D.C. Cir. 1976).

115. JUDICIAL CONFERENCE COMMITTEE REPORT, supra note 69 (discussing one of the reasons for adopting a public-is-public approach for federal court records). 
Even limiting access only to some information or documents perpetuates the inequality that remote access should overcome.

Arguing that limiting access to the courthouse for some information provides better protection for those to whom the information relates also ignores current technological realities. Practically anyone with access to a paper document can scan it and post the resulting digital document online. Paper is no longer a fixed medium. What appears on paper can now become digital. ${ }^{116}$ Optical character recognition (OCR) capability enables users to capture bits of text. ${ }^{117}$ Even if courts limit access to the courthouse, those with the resources or determination can digitize print records for their own use. One motivating reason for the Judicial Conference Committee to adopt a public-is-public approach for federal court records was to discourage "data re-sellers who, if remote electronic access were restricted, could go to the courthouse, copy the files, download the information to a private website, and charge for access ... thus profiting from the sale of public information and undermining restrictions intended to protect privacy."118 If access is limited to electronic rather than paper records, the result is the same if users can print or download the records.

Limiting access to the courthouse does not prevent someone from disseminating court records online, as a member of the Florida Supreme Court Committee on Privacy and Court Records noted. ${ }^{119}$ As an example, the member discussed how, in 2001, graphic autopsy photos of a race car driver killed while racing appeared on an Internet website. ${ }^{120}$ The website owner had obtained print photos from the Volusia County Office of the Medical Examiner in Florida. ${ }^{121}$ At the time, the photos were available as public records under Florida's public records laws. ${ }^{122}$ That same year, the Florida legislature enacted a law to exempt autopsy photographs from the public records law ${ }^{123}$ after the same website owner and others attempted to access autopsy photographs of race car driver Dale Earnhardt. ${ }^{124}$ While the photos were not court records, the situation illustrates that if a record is public, restricting access to a single physical location does not necessarily provide protection. Anyone with the motivation-like the website owner

116. Of course, textual court documents are now often "born digital," so the paper is just a medium of capture, a transitory vehicle.

117. 1 JAY E. GRENIG \& WILLIAM C. GLEISNER, III, EDisCOVERY \& DigitaL EVIDENCE $§ 15: 9$ n.1 (2012).

118. JUDICIAL CONFERENCE COMMITTEE REPORT, supra note 69. 
who posted the autopsy photos - can obtain a copy of the record, scan it, and post it for the world to see. Although providing records only at the courthouse may limit the number of people who can access documents, it only takes one person to make the documents widely available. Thus, simply managing the manner of access as the guidelines suggest offers only limited, or illusory, protection. ${ }^{125}$

The web posting of the race car driver autopsy photographs demonstrates that the balance between remote access and access only at the courthouse is really meaningless. Resolution must turn on the nature of the documents and information. If records are public, then they should be accessible through all available means. There may be reasons, based on the nature of the record or information, to limit or deny all access to those records. As Helen Nissenbaum states in her book, Privacy in Context, "[P]ublic is not synonymous with 'up for grabs'.... [E]ven if something occurs in a public space or is inscribed in a public record there may still be

119. COMM. ON PRIVACY \& COURT ReCORDS: SuPREME COURT OF Fla., Privacy, ACCESS, AND COURT RECORDS, pt. 3, at 105 (2005) [hereinafter FloridA 2005 REPORT], available at http://www.floridasupremecourt.org/pub_info/index.shtml \#Privacy (under Privacy \& Court Records, Full Report). See infra note 259 for additional discussion of this report.

120. FLORIDA 2005 REPORT, supra note 119, at 105.

121. Id. The photographs were of race car driver Neil Bonnett. Id. Gory autopsy photographs of another race car driver, Rodney Orr, also appeared online at the same time. Chris Jenkins, Web Site Posts Autopsy Photos of NASCAR Racers, USA TODAY (Apr. 2, 2001), http://www.usatoday.com/sports/comment/jenkins/200104-02-jenkins.htm. Both drivers had died in accidents at the Daytona 500 International Speedway. Id. Michael Uribe obtained the photos and posted them on his website, Websitecity.com. See Jenkins, supra.

122. See Fla. ConST. art. I, § 24; FLA. STAT. ANN. § 119.07(1)(a) (West 2008 \& Supp. 2013).

123. Fla. STAT. ANN. $\$ 406.135$ (West $2002 \&$ Supp. 2013). The statute was upheld in Campus Communications, Inc. v. Earnhardt. Campus Commc'ns, Inc. v. Earnhardt, 821 So. 2d 388 (Fla. Dist. Ct. App. 2002).

124. See Jon L. Mills, Privacy: The Lost Right 188-89, 242, 309 (2008); Samuel A. Terilli \& Sigman L. Splichal, Public Access to Autopsy and Death-Scene Photographs: Relational Privacy, Public Records and Avoidable Collisions, 10 CoMM. L. \& POL'Y 313, 313-15 (2005); Don Coble, Ten After 3: Fight over Dale Earnhardt's Autopsy Photos Leads to Victory for Family Privacy, JACKSONVILLE.COM (Feb. 11, 2011), http://jacksonville.com/sports/racing/2011-02-11/story/ten-after-3-fight-over-daleearnhardts-autopsy-photos-leads-victory.

125. STEKETEE \& CARLSON, supra note 93, at 39. 
powerful moral reasons for constraining its flow." 126 Ultimately, the question is whether anyone should have access to the records or information. ${ }^{127}$ The determination should be whether to provide access at all rather than whether to limit access to the courthouse. Also, if the record or information is extraneous to the proceedings, then not filing it in the first place alleviates this concern. ${ }^{128}$

b. Sealing. The CCJ/COSCA Guidelines offer approaches by which courts might protect personal information, other than simply segregating documents for courthouse access only. ${ }^{129}$ The CCJ/COSCA Report includes a guideline for courts, upon request, to prohibit access to information in a court record when risks of personal injury, privacy interests, public safety, or proprietary commercial information exists..$^{130}$ This denial of access essentially seals the record. The information protected in the record would otherwise be publicly available. ${ }^{131}$ Sealing is contrary to the notion of public and open access; therefore, this guideline requires "sufficient grounds" to restrict access as well as consideration of the "least restrictive means" to address the requestor's concerns. ${ }^{132}$

The CCJ/COSCA Report states that in developing court records policies, courts must review their existing "[p]rocedures and standards for sealing records, making them confidential, or otherwise restricting public access." 133 Courts must also consider how these procedures and standards

126. HelEn NisSENBAUM, PRIVACY IN CONTEXT: TECHNOlogy, Policy, AND THE INTEGRITY OF SOCIAL LIFE 217 (2010).

127. The Florida legislature can exempt certain records from the state public records access law. See Fla. Const. art. I, § 24(c); FlA. STAT. ANN. §119.15 (West 2008 \& Supp. 2013). For example, the Florida legislature determined that it was a "public necessity" to exempt autopsy photographs from the public access to records granted by the Florida constitution and public records law. Act of Mar. 29, 2001, ch. 2001-1, 2001 Fla. Laws 1, 2-3. The legislature noted the injury to the person's family if there was public access to graphic autopsy photographs, particularly if these photographs were posted on the Internet. $I d$. at 2 . The legislature also noted that there were other types of autopsy information available to the public that would "provide for public oversight." Id.

128. See infra Part V for further discussion of this approach.

129. See generally STEKETEE \& CARLSON, supra note 93.

130. Id. at 53.

131. See id. at 54.

132. Id. at 53 .

133. Id. at 2 . 
might apply to electronic records. This review must ensure that procedures and policies balance the requests of a party against a strong public policy of access to records. People and businesses often do not want any information about a lawsuit made available to the public, and they will seek protection through sealing. In the last decade, there has been a public outcry, fostered by media reports, against indiscriminate sealing of records. ${ }^{134}$ Some states have since enacted or revised sealing laws. ${ }^{135}$ For example, in 2007 the Florida Supreme Court adopted revisions to court rules that governed sealing and unsealing of records, after media exposure of "hidden cases and secret dockets." 136 The court further refined these rules in 2010.137 Florida's review of its rules regarding sealing and confidential documents illustrates the thorough consideration a court should make when developing and adopting policies regarding access to electronic court records. ${ }^{138}$ The policies should address the underlying concerns regarding sealing, regardless of the format of the documents.

c. Redaction. Another CCJ/COSCA guideline suggests blocking access to sensitive information, such as social security numbers, and discusses specific types of information that a court could exclude from public access. ${ }^{139}$ However, the CCJ/COSCA Guidelines do not specifically discuss how to block access to this information. A common means of blocking specific information is redaction, but the section on exclusion of information within the guidelines does not discuss redaction. Commentary to two sections of the guidelines notes the difficulty a court may experience

134. See, e.g., Thomas Mitchell, The Heavy Lifting Begins, LAS VEGAS REv. -J., Jan. 6, 2008, at 2D, available at 2008 WLNR 388914 (discussing reform in Nevada); Florida Supreme Court Enacts Interim Rules for Sealing Civil Records, FIN. NEws \& DAILY REC. (Apr. 27, 2007), http://www.jaxdailyrecord.com/showstory.php?Story_id $=47427$.

135. See, e.g., Fla. R. Jud. Admin. 2.420; NEV. SuP. CT. R. pt. VII; OHIo SuP. R. 45 ; S.C. R. CIV. P. 41.1.

136. In re Amendments to Fla. Rule of Judicial Admin. 2.420-Sealing of Court Records \& Dockets, 954 So. 2d 16, 17 (Fla. 2007).

137. In re Amendments to Fla. Rule of Judicial Admin. 2.420 \& the Fla. Rules of Appellate Procedure, 31 So. 3d 756, 757-58 (Fla. 2010).

138. See generally id. (reviewing the development and adoption process and explaining the rules and their effect); In re Amendments to Fla. Rule of Judicial Admin. 2.420 - Sealing of Court Records \& Dockets, 954 So. 2d 16 (discussing why procedures to seal court records were needed).

139. See STEKETEE \& CARLSON, supra note 93, at 45-52. 
in redacting information in documents. ${ }^{140}$ The comments focus on the costs and feasibility of having court personnel redact information. ${ }^{141}$ There is no discussion of whether the parties should be responsible for redaction, just as there are no suggested policies for placing the redaction burden on the parties and their counsel.

Redaction of information is a common choice for courts adopting electronic records policies. This approach protects sensitive information, while still providing access to most of the information in a document. As sensible as redaction may seem, it presents logistical problems. The limited discussion of this approach in the CCJ/COSCA Guidelines notes the demands of having court personnel handle redaction. ${ }^{142}$ Parties and their counsel are in a better position to identify and block information. However, this burden may still be too great and its requirements too confusing, as efforts to apply redaction rules in Montana illustrate..$^{143}$ Parties may find it more practical to request that a court seal an entire document or record rather than try to redact selected bits of information. ${ }^{144}$ For example, in Montana, parties coped with redaction rules by sealing the records. ${ }^{145}$ Electronic records policies that require redaction or allow for redaction upon request may increase the use of sealing as an easier way of prohibiting access to the information, leading to a loss in public access to the entire record. Part V of this Article discusses an approach that would eliminate personal information from inclusion in court documents thus reducing the need for resources to redact the information.

140. See id. at 17-18 (mentioning that redacting information can be "quite costly"); id. at 55 (noting the feasibility of reviewing documents to redact information).

141. $\quad I d$. at $17-18,55$.

142. Id. at 55 .

143. See discussion infra Part IV.B.2.a.

144. STEKETEE \& CARLSON, supra note 93, at 55. "The work needed to exhaustively review a large file or document to find information to be redacted may be prohibitive, such that access to the whole file or document [should] be restricted, rather than attempting redaction." Id.

145. See Petition of Montana Legal Services Association and State Law Librarian Judy Meadows at 2, In re Amending the Rules for Privacy \& Pub. Access to Court Records in Mont., No. AF 06-0377 (Mont. Oct. 12, 2010) [hereinafter 2010 Petition], available at http://supremecourtdocket.mt.gov/view/AF\%2006-0377\%20Rule \%20Change \%20--\%20Petition?id=\{1327D05A-4588-4D17-AE60-AF345CFEBF57\}; discussion infra Part IV.B.2.a. 


\section{Other Issues and Concerns}

a. Implementation planning: Montana's experience. The CCJ/COSCA Guidelines provide a framework for developing what the rules will provide, but implementation requires another process to consider how the rules will work. ${ }^{146}$ The guidelines do not "prescribe standard implementation and operating guidelines for state and local courts."147 For example, there is little information in the CCJ/COSCA Guidelines concerning redaction. ${ }^{148}$ One guideline considers limits on remote availability of documents and information, yet provides limited commentary as to who would have the responsibility of deciding what specific information or documents cannot be made available remotely. ${ }^{149}$ Commentary to this guideline briefly discusses the "added burdens" court staff would have to assume if the parties do not bear the burden of providing a list of information items to which the court will restrict access; ${ }^{150}$ however, the commentary offers no further advice. Implementation can be the most challenging aspect of defining the information and documents to which the public has access, particularly as courts are transitioning to e-filing.

A compelling example of the effects of the lack of implementation planning is the experience in Montana. The process of adopting rules for public access to electronic court records started in Montana in 2005. ${ }^{151}$ While rules went into effect in 2008, ${ }^{152}$ by 2011 the Montana Supreme Court had suspended the rules for an indefinite period of time. ${ }^{153}$ A lack of

146. See generally STEKETEE \& CARLSON, supra note 93.

147. Steketee \& Carlson, supra note 95, at 24.

148. See supra Part IV.B.1.c.

149. STEKETEE \& CARLSON, supra note 93, at 39.

150. See id. at 41.

151. Order at 1, In re Rules for Pub. Access to Court Records, No. AF 06-0377 (Mont. May 23, 2006) [hereinafter 2006 Public Access], available at http://supremecourtdocket.mt.gov/view/AF\%2006-0377\%20Comments-Request \%20$\%$ 20Order?id=\%7b506005E1-1CB3-43D7-8125-92C8CFD1CBD0\%7d.

152. Order at 2, In re Adopting Rules for Pub. Access \& Privacy to Court Records in Mont., No. AF 06-0377 (Mont. Dec. 12, 2007) [hereinafter 2007 Public Access], available at http://supremecourtdocket.mt.gov/view/AF\%2006-0377\%20Grant \%20--\%20Order?id=\{30B411BF-A416-4619-A28E-5FCD8EFDB691\}.

153. Order at 1 , In re Temporarily Suspending the Rules for Privacy \& Pub. Access to Court Records in Mont., No. AF 06-0377 (Mont. Sept. 14, 2011) [hereinafter 2011 Public Access], available at http://supremecourtdocket.mt.gov.view/AF\%20060377\%20Other\%20--\%20Order?id=\{9D33F333-4838-4ED4-9302-6EB4EFA01640]. 
procedures had derailed the implementation. ${ }^{154}$ The initial process for creation and adoption of rules moved very quickly. ${ }^{155}$ In 2005, the Montana Supreme Court's Commission on Technology created a task force to develop rules for access to electronic court records. ${ }^{156}$ This task force used the CCJ/COSCA Guidelines as its model, extensively adopting language from the guidelines and the commentary to the guidelines. ${ }^{157}$ The task force proposed rules in less than a year. ${ }^{158}$ In February 2007, the Montana Supreme Court adopted the rules, which were to become effective on December 31, 2007.159

Concerns arose almost immediately. By December 2007, the concerns had reached such a high level that task force leaders filed a petition requesting postponement of the implementation of the rules to July 2008 in order to allow time to gather comments and provide more implementation

154. 2007 Public Access, supra note 152, at 1.

155. See 2006 Public Access, supra note 151, at 1-2.

156. Id. at 1 . The impetus for creation of rules came in 2003 , when the Montana Supreme Court adopted a goal of providing "electronic access to and exchange of information." MONT. JUDICIAL BRANCH, INFORMATION TECHNOLOGY STRATEGIC PLAN 11 (2003), available at http://wcc.dli.mt.gov/E-Filing/MT\%20Jud \%20Branch\%20StrategicPlanMarch2003.pdf; see also MONT. JUDICIAL BRANCH, InFORMATION TECHNOLOGY STRATEGIC Plan 8 (2006), available at http://courts.mt .gov/content/cao/docs/it_strategic_plan_06.

157. See 2006 Public Access, supra note 151, at 1. For a copy of the original proposed rules and commentary, see Order at app. A, In re Rules for Pub. Access to Court Records (Mont. Feb. 13, 2007) [hereinafter February 2007 Order], available at http://supremecourtdocket.mt.gov/view/AF\%2006-0377\%20Rule\%20Change\%20-\%20Order?id=\{B8D81F96-A18A-4CF5-A613-8CB5514D06CB $\}$. The Task Force adapted the CCJ/COSCA Guidelines to fit Montana laws and rules and to comply with Montana's constitutional provisions guaranteeing the right of individual privacy and the right to examine documents. See 2006 Public Access, supra note 151, at 1-2. The constitutional provisions are: MONT. CONST. art. II, $\S 9$ ("No person shall be deprived of the right to examine documents . . . of all public bodies or agencies of state government and its subdivisions, except in cases in which the demand of individual privacy clearly exceeds the merits of public disclosure.") and $\S 10$ ("The right of individual privacy is essential to the well-being of a free society and shall not be infringed without the showing of a compelling state interest.").

158. See 2006 Public Access, supra note 151, at 1-2. The Montana Supreme Court's Commission on Technology established a task force in November 2005. Id. at 1. The commission voted to recommend the proposed rules on May 15, 2006; the production of the rules and commentary thus took approximately six months. See id. at 2.

159. February 2007 Order, supra note 157 , at 1. 
guidance. ${ }^{160}$ The leaders of the task force stated in the petition that, after attempting to educate court personnel about the new rules, they were genuinely concerned that "the Courts [were] not yet ready to implement the Rules." 161 One issue was that many court forms required information to which the rules restricted access, even though state law did not require disclosure of the information. ${ }^{162}$ This created confusion regarding the application of the rules. ${ }^{163}$ The Montana Supreme Court, therefore, granted the requested postponement. ${ }^{164}$ At the same time that the task force leaders filed this petition, a group of Montana district court judges and two attorneys filed a petition ${ }^{165}$ questioning the implementation of the rules at a time when there was no system in existence for e-filing. ${ }^{166}$ The group of judges and attorneys requested that the court suspend implementation of the rules until electronic filing was available. ${ }^{167}$ The court ruled that the proceedings regarding the new rules were administrative, not adversarial;

160. Petition to Amend and Extend Implementation Deadline at 1-3, In re Adopting Rules for Pub. Access \& Privacy to Court Records in Mont., No. AF 06-0377 (Mont. Dec 11, 2007) [hereinafter Petition to Amend], available at http://supremecourtdocket.mt.gov/view/AF\%2006-0377\%20Other\%20--\%20Petition ?id $=\{$ F9C38A6E-92CA-47E7-B3ED-E33CDA7B386A $\}$.

161. Id. at 2.

162. See id.

163. Id.

164. 2007 Public Access, supra note 152, at 2.

165. Petition for Original Jurisdiction and Order at 1, In re Rules for Privacy \& Pub. Access to Court Records in Mont., No. AF 06-0377 (Mont. Dec. 19, 2007) [hereinafter Petition for Original Jurisdiction], available at http://statecasefiles.justia .com/documents/montana/supreme-court/2007-12-20-DCFD82F3-CA54-4AC2-A54ED2F63265C1C1.pdf.

166. See Petition for Original Jurisdiction and Order at 6, In re Rules for Privacy \& Pub. Access to Court Records in Mont., No. AF 06-0377 (Mont. Dec. 19, 2007) [hereinafter Petition for Original Jurisdiction], available at http://statecasefiles .justia.com/documents/montana/supreme-court/2007-12-20-DCFD82F3-CA54-4AC2-

A54E-D2F63265C1C1.pdf ("No technology is currently available to the District Courts or attorneys practicing before the District Courts for any of these documents to be filed in electronic form."). The petition noted that in 2006, the Montana Supreme Court Information Technology Strategic Plan had set objectives to develop and implement an electronic filing system within four years. $I d$. at 4-5. Since this system was not in existence, the new rules would only apply to paper filings. There were no procedures or forms available to assist with compliance, thus, the petitioners argued that there would need to be procedures, forms, and training relating to the application of the rules to paper filings, and then additional procedures, forms, and training when e-filing became available. See id. at 10.

167. Id. at 14. 
therefore, the court referred the petition to the task force..$^{168}$

In June 2008, the Montana Supreme Court adopted revised rules that the task force recommended. ${ }^{169}$ The revised rules provided that courts should not place court records online, with certain exceptions, until rules for electronic filing were in place. ${ }^{170}$ At the same time, the rules concerning the type of information that had to be excluded from records remained in effect, regardless of format. ${ }^{171}$ By 2010 , just two years after the effective date of the new rules, questions and doubts about compliance arose. A petition filed with the Montana Supreme court in October 2010 argued that compliance with the rules was "haphazard at best."172 Particularly challenging was compliance with rules governing exclusion from public access of sensitive information and certain documents. ${ }^{173}$ Some people were "struggling to comply" even though courts were not consistently interpreting and applying the rules, while others were "making no attempt whatsoever to comply." 174 Petitioners were also concerned that some people were simply "moving to seal court records in most or all cases," thus removing the entire record from public access. ${ }^{175}$

168. Order at 3-4, In re Pub. Access \& Privacy to Court Records in Mont., No. AF 06-0377 (Mont. Jan. 9, 2008), available at http://supremecourtdocket.mt.gov /view/AF\%2006-0377\%20Other\%20--\%20Order?id=|6D22BFAA-EA4A-4684-9C69613E1C0480FE\}.

169. Order at 2-4, In re Amending the Rules for Pub. Access \& Privacy to Court Records in Mont., No. AF 06-0377 (Mont. June 24, 2008) [hereinafter Order Amending the Rules], available at http://supremecourtdocket.mt.gov/view/AF\%20060377\%20Rule \%20Change\%20--\%20Order?id=\{73D46187-DE84-4746-A56C-05D93 004B066\}. The two rules with revisions were 4.0 and 4.20 . Id. at $2-4$. The other rules were not changed. The revised rules were in a task force report submitted in June 2008, and the rules became effective July 1, 2008. Id. at 5. MONT. SUPREME COURT COMM'N ON TECH. PRIVACY \& ACCESS TASKFORCE, REPORT TO THE COURT Following 2008 COMMENT PERIOD 1 (2008), available at http://supremecourtdocket.mt.gov/view/AF \%2006-0377\%20Other\%20--\%20Other? id=|49293049-B47C-4AB2-AA0A-1B658AF8 $715 \mathrm{~A}]$.

170. See Order Amending the Rules, supra note 169, at 3-4. The exceptions listed in Section 4.20 included: party indexes, listings of new case filings, and calendars or dockets. Id.

171. See Mont. R. PRIVACY \& Public ACCESS to COURT Records IN MONT. $\S \S 4.0,4.50$ (suspended in 2011).

172. 2010 Petition, supra note 145, at 2; see 2011 Public Access, supra note 153, at 1 .

173. See id.

174. Id.

175. Id. There were also concerns that the rules needed to provide more 
The 2010 petitioners observed that since the court had not adopted an e-filing system and rules, the rules on access to court records operated in "a sort of limbo between the current 'paper world' and the largely unknown future e-filing and remote access world." ${ }^{176}$ It did not appear that the implementation of an e-filing system would occur in the near future; $;{ }^{177}$ therefore, the petitioners recommended that the court consider suspending all or part of the access rules until adoption of an e-filing system and related rules. ${ }^{178}$ The Montana Supreme Court, in September 2011, ordered that the rules be "temporarily suspended, for an indefinite period of time." 179 The court noted its desire to have privacy rules "further considered, reviewed and refined" as part of the process of adopting and implementing e-filing. ${ }^{180}$

Montana's experience demonstrates the need to examine the effects of proposed rules and to develop strategies prior to adoption to determine how the rules will work in practice. One participant in the process stated that providing an ideal court records system was "much easier said than

protection for information about children. Id. at 3-4.

176. Id. at 11.

177. Id. at 10. Objective 3.1 .3 of the 2010 Montana Judicial Branch Information Technology Strategic Plan identified as an action item for 2011-2014 continuance of "the efforts of the Electronic Filing Task Force to procure and implement a statewide system for electronic filing in all Montana courts." COMM'N ON TeCh., Mont. Judicial BRanch, Information TeChNology Strategic Plan 15 (2010), available at http://courts.mt.gov/content/cao/docs/it_strategic_plan_2010.pdf.

178. 2010 Petition, supra note 145 , at 10 . The petition also contained alternative proposals for amending the rules if the court did not decide to suspend the rules. Id. at 3.

179. 2011 Public Access, supra note 153, at 2. The suspension was effective as of October 1, 2011. Id. One justice did not sign the order. Id. at 3-4. He noted the extensive work of the task force and argued that the existing rules remained "a solid and workable platform." Id. (statement of Justice James C. Nelson). In his view, it was better that the bench and bar became "accustomed ... to the sorts of requirements that e-filing will eventually dictate." Id. at 4.

180. Id. at 2. The court also noted the April 2011 adoption of Montana Rule of Civil Procedure 5.2, which would provide some privacy protections. Id. at 1 . The adoption of this rule was part of a comprehensive revision to the Montana Rules of Civil Procedure. See Order at 1, In re Revisions to the Mont. Rules of Civil Procedure, No. AF 07-0157 (Mont. Apr. 26, 2011), available at http://supremecourtdocket.mt.gov $/$ view/AF\%2007-0157\%20Rule\%20Change\%20--\%20Order?id=\%7bE034623C-49D446B7-85A1-CE3DBBED0D04\%7d. The new rule is similar to Federal Rule of Civil Procedure 5.2, which provides for redaction of sensitive information. Id:; MONT. R. Civ. P. 5.2. 
done."181 The Montana task force was made up of a wide range of stakeholders to ensure input from those with the most interest in the policies. ${ }^{182}$ The task force based its recommendations on the CCJ/COSCA Guidelines, which provided a thorough and thoughtful roadmap. ${ }^{183}$ Yet, implementation of the rules quickly became problematic and ultimately the Montana Supreme Court suspended the rules. ${ }^{184}$ The task force developed the rules, but no task force or committee was charged with developing the procedures for implementation. ${ }^{185}$ The result was confusion in interpretation, compliance, and enforcement. ${ }^{186}$

b. Retention of records. Some of the more far-reaching issues with providing access to electronic court records focus on the retention of these records. Some issues are rooted in the "dual nature of today's court recordkeeping system." 187 Courts are maintaining both paper and electronic records, and may hold the same records in both formats. ${ }^{188}$ The CCJ/COSCA Report does not contain specific guidelines for the retention of records, but it notes in commentary some of the issues with a dual system. ${ }^{189}$ Problems can arise when there are changes in records, when a court removes records, or when a court destroys records that have a short retention period. ${ }^{190}$ The initial consideration in these situations is to provide equivalent treatment for the print record and its electronic

181. 2010 Petition, supra note 145 , at 1.

182. See February 2007 Order, supra note 157, at 1.

$183 . \quad I d$.

184. 2011 Public Access, supra note 153, at 2.

185. See Petition for Original Jurisdiction, supra note 166, at 6-7 ("Neither the Task Force appointed by the Commission on Technology nor any other commission or task force has been authorized ... to establish procedures or adopt official forms to establish how ... to comply with the Access Rules ....").

186. See 2010 Petition, supra note 145, at 2 ("Nor do the Privacy Rules contain specific guidance about their implementation ... . , which has led to diverging interpretations over how to protect information and what kinds of information must be redacted or included.").

187. JENNEN, supra note 41, at 27.

188. Id. at 8.

189. See STEKETEE \& CARLSON, supra note 93, at 25.

190. Id. Some of the examples provided in the commentary are: (1) a change in a reduction in criminal conviction after probation completion; (2) the expunging of a record; and (3) destruction of certain types of records, such as traffic citations, after a short period of time. Id. 
counterpart. ${ }^{191}$

The goals of providing equal treatment to electronic and print records are to ensure that there is not an outdated version of a record available and that there is no longer public access to a record the court has removed or destroyed. This equal treatment policy seems straightforward. The nature of electronic records, however, raises additional issues. In developing and adopting remote public access policies, courts must examine existing laws, policies, and procedures beyond just determining how to equalize treatment of print and electronic records. ${ }^{192}$ Courts should consider the purpose of existing provisions and their effectiveness when applied to electronic records. ${ }^{193}$

As an example of considering the purpose of existing provisions, the $\mathrm{CCJ} / \mathrm{COSCA}$ Report commentary considers a rule regarding destruction of traffic citations after one year. ${ }^{194}$ The purpose of the rule could be to free up storage space occupied by paper documents. ${ }^{195}$ In this case, the court should consider the need for this rule if the records are electronic. ${ }^{196}$ Maintaining documents in electronic form furthers the policy of public access. On the other hand, if the purpose of destroying the citation records is to clear a person's record of this type of violation, then the policy of destroying records after one year should remain in place whether the record is in electronic form or in paper. ${ }^{197}$

191. See id. An example of a state court system that has standardized retention policies for electronic and print records is Pennsylvania. Press Release, Admin. Office of Pa. Courts, Retention of Paper and Electronic Court Records to be Consistent Under New Guidelines (March 30, 2012), available at http://www.pacourts.us/assets/files/newsrelease-1/file-1229.pdf. Once the retention period for the paper records expires, the electronic record will no longer be available. State Destroying Online Court Records, Raising Debate over Privacy, Consistency, TRIB.-REV. (July 2, 2012), http://triblive.com/news/2134478-74/records-public-privacystate-court-pennsylvania-policy-schell-copy-courts.

192. STEKETEE \& CARLSON, supra note 93, at 2.

193. See id. at 3.

194. Id. at 25 .

195. Id.

196. See id. It is unclear in this scenario if the records are now all electronic or whether the paper records still exists. If there is no reason to destroy the record other than for space-saving sake, then perhaps the court should retain the electronic record. If there are both paper and electronic versions, then the court could destroy the paper version.

197. Id. 
Another problem arises from the inability to destroy records. "[I]t is impossible to ensure destruction of all copies of the electronic record that have been obtained by, or delivered to, third parties beyond the court's control." 198 Of course, it is also possible that there could be copies of the paper record still available. ${ }^{199}$ If a record was ever publicly available, a copy may still exist. Moreover, the dissemination of electronic records is much further reaching, and therefore destruction becomes more problematic. With respect to paper records, it takes only one person to scan and disseminate a record. ${ }^{200}$

The issues discussed above occur when there is a dual print and electronic system of maintaining court records. Questions arise as to how to treat electronic versions of records also maintained in paper. While courts will inevitably consider resolution of these issues, they should go further than just adopting rules for electronic records. As the Florida Committee on Privacy and Court Records noted in its 2005 report, the task is

not merely to create an electronic access policy as a companion to an "over the counter" records policy, but to create a blueprint for a comprehensive policy on court records that will serve the public and the courts as they move through the transition from a system of primarily paper records to one of primarily digital records. ${ }^{201}$

Policy development must include consideration of the nature of electronic records and how that impacts records retention. Just as the nature of electronic records affects the way people access records, it also has implications relating to ongoing retention. Yet, as authors JeanFrançois Blanchette and Deborah Johnson note, discussions regarding electronic information management focus on access "and address retention

198.

Id. As Viktor Mayer-Schönberger discusses in Delete: The Virtue of Forgetting in the Digital Age: "In the digital age, it has become very hard to recall information, and to stop others from sharing it, especially once a piece of information has begun to spread ...." VIKTOR MAYER-SCHÖNBERGER, DELETE: THE VIRTUE OF ForgetTing In The Digital AgE 87 (2009).

199. In The Verdict, a witness in a trial reveals while she is on the stand that she has a photocopy of the original, unaltered version of a critical document in the case. THE VERDICT (Twentieth Century Fox 1982). She made the copy before she had to alter the original under threat. Id. This example illustrates that the existence of even one copy of a document, no matter how it is obtained, can be devastating. Id.

200. See supra text accompanying notes 121-29.

201. FLORIDA 2005 REPORT, supra note 119, pt. 1, at 7. 
only as an afterthought-if at all." 202 They maintain that "[d]ata retention must be ... part of a comprehensive data protection policy" 203 because "the endurance of data is a feature that has invisibly but powerfully changed with the shift from paper-and-ink to electronic systems of recordkeeping." "04 In a "paper-and-ink world, the sheer cumbersomeness of archiving and later finding information often promote[s] a form of institutional forgetfulness." 205 Electronic records, on the other hand, remain easily and indefinitely accessible, thus preserving their contents for immediate consideration at any time.

The indefinite life of online data and information raises a concern that "the Internet records everything and forgets nothing." 206 Blanchette and Johnson observe that "[i]n many cases, as storage technologies have gained in practicality, ease of remote access, and lowered in price, the shift to an electronic medium changed the default position from one of forgetfulness to one of memory." 207 What they are referring to is a loss of "social forgetfulness, which allows individuals a second chance, the opportunity for a fresh start in life." ${ }^{208}$ Cases settle, defendants found liable pay damages, and defendants in criminal cases serve jail time. People should be able to move on, start over, get a fresh start, and leave the past behind. The constant and easy availability of electronic records, however, can inhibit the ability of people to escape the past. ${ }^{209}$ As Daniel Solove notes: "People grow and change, and disclosures of information from their

202. Jean-François Blanchette \& Deborah G. Johnson, Data Retention and the Panoptic Society: The Social Benefits of Forgetfulness, 18 INFO. SoC'Y 33, 34 (2002).

203. Id. at 43.

204. Id. at 34 .

205. Id.

206. Jeffrey Rosen, The End of Forgetting, N.Y. TIMEs MAG., July 25, 2010, at 30,32 .

207. Blanchette \& Johnson, supra note 202, at 34 (footnote omitted); see also MAYER-SCHÖNBERGER, supra note 198, at 91 ("Through cheap storage technology, keeping digital information has become not only affordable, but frequently cheaper than taking the time to selectively delete some of it.... The result is a world that is set to remember, and that has little if any incentive to forget.").

208. Blanchette \& Johnson, supra note 202, at 33; see DANIEL J. SOLOVE, THE Future of REPUTATION: GOSSIP, RUMOR, AND PRIVACY ON THE INTERNET 72-73 (2007).

209. Blanchette \& Johnson, supra note 202, at 35; see also GARY T. MARX, UNDERCOVER: POLICE SURVEILLANCE IN AMERICA 223 (1988) ("[W]ith the mass of easily accessible files, one's past is always present . . . "); J.D. Lasica, The Net Never Forgets, SALON (Nov. 25, 1998), http://www.salon.com/1998/11/25/feature_253/ ("[O]ur pasts are becoming etched like a tattoo into our digital skins."). 
past can inhibit their ability to reform their behavior, to have a second chance, or to alter their life's direction."210 An extensive discussion of electronic records retention and social forgetfulness is beyond the scope of this Article. ${ }^{211}$ Suffice it to say that policy development for electronic records requires a consideration of the nature of information in the records and a rethinking of retention rules. ${ }^{212}$ This consideration should include how preservation of a person's past in a highly accessible form might change the approach to both the access and retention of records. ${ }^{213}$

c. Accuracy problems and dossier creation. The ease of access to electronic court records also raises concerns about the use of the information in the records. Court records contain more than the details of an episode in a person's life. ${ }^{214}$ They contain a treasure trove of personal information. ${ }^{215}$ Some bits of personal information may seem unimportant in isolation, and in the context of a court case, may serve merely as identifiers. ${ }^{216}$ Yet certain pieces of information, such as a social security number, can provide the keys to assuming the identity of an individual as well as learning highly personal information. ${ }^{217}$ Also, third-party collection of this information can lead to what Daniel Solove calls "the aggregation effect." 218 This effect arises from combining bits of information about an

210. (2006).

Daniel J. Solove, A Taxonomy of Privacy, 154 U. PA. L. REV. 477, 533

211.

For more discussion of social forgetfulness, see MAYER-SCHÖNBERGER, supra note 198; Blanchette \& Johnson, supra note 202; Morrison, supra note 6, at 919; Rosen, supra note 206; Lasica, supra note 209.

212. See STEKETEE \& CARLSON, supra note 93, at 25.

213. In its short discussion of retention of records, the CCJ/COSCA Report struggled with how to adapt a short retention policy for certain records such as traffic citations to electronic versions of these records. If the reason for a short retention period is to clear a person's record, then the report suggests "a policy that the electronic record not be accessible" or a policy that "no electronic version of the record would be made." Id. The concern is that once the record is in electronic form, the information is no longer under the court's control. See id.; see also supra text accompanying notes 204-06.

214. Daniel J. Solove, Access and Aggregation: Public Records, Privacy and the Constitution, 86 MinN. L. REV. 1137, 1146-48 (2002).

215. See id.

216. Id. at 1185 .

217. Daniel J. Solove, The Digital Person: Technology \& Privacy in THE INFORMATION AGE 44 (2004); see also Solove, supra note 214, at 1185.

218. SOLOVE, supra note 217 , at 44 ; Solove, supra note 214 , at 1185. 
individual. ${ }^{219}$ The individual may provide these pieces of information in different contexts and at different times. As Solove explains, once these pieces are combined, they "begin to form a portrait of a person. The whole becomes greater than the parts.... When analyzed, aggregated information can reveal new facts about a person that she did not expect would be known about her when the original, isolated data was collected." 220 Public records, including court records, are a rich source of aggregated information. ${ }^{221}$ This aggregated information can become part of an individual "digital dossier."222 This dossier or digital portrait of a person can be very blurry, distorted, and superficial. ${ }^{223}$ The portrait is also often inaccurate. ${ }^{224}$ Sometimes data is simply incorrect (e.g., the person never lived at a certain address). ${ }^{225}$ Other times distortion comes from lack of detail and loss of the information's context. ${ }^{226}$ This issue especially arises with court records that contain unproven allegations that may have simply been false. ${ }^{227}$ Also, the outcome of a lawsuit and the effect on a party to that suit might not be readily known.

It is possible to create an instant snapshot of a person simply through a Google search. The view that emerges from such a search (even if the searcher eliminates false hits) is murky; a hodgepodge of hits from disparate sites. It is now common in conducting an Internet search to "net" court records, particularly pleadings. Pleadings, of course, are merely the tip of a lawsuit. Lawsuits often settle, and the context of the suit disappears. Some researchers, when finding evidence of a lawsuit, may investigate further, while others might simply note the person's role in the lawsuit. The problems multiply for persons who are defendants in a lawsuit. Allegations about defendants are often distorted or untrue, and create a misleading view of the defendant. The person may not be ultimately liable (or guilty),

\footnotetext{
219. SOLOVE, supra note 217 , at 44 .

220. Daniel J. Solove, Understanding PRIVACy 118 (2008) (footnote omitted).

221. See Solove, supra note 214, at 1145 ("Court records are potentially the most revealing records about individuals.").

222. See Solove, supra note 217, at 1-3.

223. Id. at $45-46$.

224. Id. at 46.

225. Id. at 21.

226. See Solove, supra note 210, at 508-09; see also Solove, supra note 214, at 1188.

227. See Anderson, supra note 33, at 10.
} 
but this piece of information may be lost. There are also problems for plaintiffs. Some people may infer that if a person is a plaintiff in a lawsuit, that person is a "complainer" or someone who will "make trouble"228 irrespective of the merits of the plaintiff's claim. While the collection of information in a digital dossier or portrait often represents a distorted and inaccurate view of a person, people may rely on this information to make judgments and decisions. As Daniel Solove describes: "The problem is that such records often fail to tell the entire story, yet an individual is frequently judged on the basis of this information and important facets about her life - whether she gets a loan, a job, or a license-are decided based upon this information." 229

d. Loss of context. The digital dossier consists of information that gatherers take out of its original context (e.g., a court case). The person who provided the information in a lawsuit usually has no knowledge of this information gathering. The information compilers then incorporate this information into other, unrelated contexts. ${ }^{230}$ As Helen Nissenbaum notes: "[T] he process of compiling and aggregating information almost always involves shifting information taken from an appropriate context and inserting it into one perceived not to be so." ${ }^{231}$ According to Nissenbaum, this shift violates "contextual integrity." 232 "Contexts are structured social settings" with "activities, roles, relationships, power structures, norms (or rules), and internal values (goals, ends, purposes)."233 A lawsuit is one context in which information disclosure occurs in a structured setting with the characteristics Nissenbaum describes. Nissenbaum does not view the

228.

For an example of negative impressions of plaintiffs see NISSENBAUM, supra note 126, at 55 (quoting Higg-a-Rella, Inc. v. Cnty. of Essex, 660 A.2d 1163, 1172 (N.J. 1995)) (noting that "doctors can search for medical-malpractice claims to avoid treating litigious patients; employers can search for workers'-compensation claims to avoid hiring those who have previously filed such claims").

229. Daniel J. Solove, Privacy and Power: Computer Databases and Metaphors for Information Privacy, 53 STAN. L. REV. 1393, 1424 (2001); see also Solove, supra note 210 , at 508 (noting that the focus on the "digital person" for decision making "increasingly is affecting the flesh-and-blood individual in realspace" (footnote omitted)).

230. See Solove, supra note 210, at 508-09 ("Data compilations are often both telling and incomplete. They reveal facets of our lives, but the data is often reductive and disconnected from the original context in which it was gathered.").

231. Nissenbaum, supra note 3, at 589.

232. See id. at 581-82.

233. NISSENBAUM, supra note 126, at 132. 
Internet as a separate context. ${ }^{234}$ Context exists aside from the Internet. The expectations of a person providing information do not change merely because the information is online. For example, people have certain expectations regarding confidentiality of banking and financial information, and expect retention of this confidentiality even when the information is accessible online. ${ }^{235}$

A violation of contextual integrity is a violation of a person's expectations regarding the use of information that he or she gave for a specific purpose. Daniel Solove observes that "[r]ules of evidence determine the admissibility of information based not only on the information's content, but also on the circumstances in which it is gathered, who is disclosing it, and what purpose its disclosure aims to achieve."236 Applying this approach to information that people have provided, he argues that instead of a distinction between what information may be private or public, the focus should be on "the appropriateness of the disclosure in context." 237

Some might argue that people are not very concerned about privacy as evidenced by the extensive use of social networking and other online means of disseminating personal information. ${ }^{238}$ Many of the postings that

234. Helen Nissenbaum, A Contextual Approach to Privacy Online, 140 DÆDALus 32, 38 (2011) ("The Net does not constitute (drawing on the terminology of contextual integrity) a discrete context.").

235. See id. at 39,41 .

236. Daniel J. Solove, The Virtues of Knowing Less: Justifying Privacy Protections Against Disclosure, 53 DUKE L.J. 967, 1013 (2003). For example, there is protection of communications between attorney and client, and husband and wife. Id. at 1015 .

237. Id. at 1013 (footnote omitted). Solove states that "[a] disclosure that may be appropriate in one public context ... may not be appropriate in another public context." Id. For further discussion, see id. at 1013-1019. Helen Nissenbaum has also noted that relationships, such as that between a doctor and patient, change the expectation regarding disclosure of information. See Nissenbaum, supra note 3, at 594.

238. See NiSSENBAUM, supra note 126, at 105-07 ("[S]keptics would have us conclude that people's actions convey the message loudly and clearly that privacy is not of great value after all ...."); see also Interview by Michael Arrington with Mark Zuckerberg, CEO, Facebook, in S.F., Cal. (Jan. 8, 2010), available at http://www.youtube.com/watch?v=LoWKGBloMsU. In that interview, Zuckerberg stated: "People have really gotten comfortable not only sharing more information, and different kinds, but more openly and with more people. And that social norm is just something that has evolved over time." Id. 
people make are voluntary, yet it is highly unlikely that posters really understand the uses to which their information can be put. ${ }^{239}$ Many people probably are not aware that court records are open, ${ }^{240}$ much less that third parties might use the information from such records. The CCJ/COSCA Report contained provisions regarding education of the public concerning the implications of public access to court records. ${ }^{241} \mathrm{~A}$ follow-up report in 2005 provided a template for educational materials, recognizing that "the public, and litigants in particular, may not always be aware that the information in court records is open. Some may assume some or all of it is private." 242 There are concerns that once people understand the implications of open court records on the Internet there might be a chilling effect on participation and willingness to disclose information. ${ }^{243}$

Posting information on Facebook or in a video on YouTube is different from disclosing information in other contexts, such as information stemming from a lawsuit. As noted above, the Internet is not a context. ${ }^{244}$ Expectations regarding the use of information relate to the original context of its disclosure. As Solove states: "Information is disclosed for a particular reason or goal. Disclosure occurs through particular uses of information, and therefore, not all disclosures of information are the same."245 The use of the Internet as a medium does not change these expectations. ${ }^{246}$ The posting of court records online thus raises significant issues about the loss of contextual integrity and its implications for those involved in lawsuits.

239. See NisSENBAUM, supra note 126, at 105 ("[P]eople often are not fully aware that at certain critical junctures information is being gathered or recorded. Nor do they fully grasp the implications of the informational ecology in which they choose and act.").

240. Daniel Solove suggests that people have little idea of potential secondary uses of information, even when they receive policies that suggest there can be secondary use. Solove, supra note 210 , at 520 .

241. STEKETEE \& CARLSON, supra note 93, at 64 .

242. CARLSON \& STEKETEE, supra note 94, at 1.

243. See Judicial Mgmt. Council of Fla., Privacy and Electronic ACCESS TO COURT RECORDS: REPORT AND RECOMMENDATIONS 36 (2001) [hereinafter FLORIDA 2001 REPORT], available at http://www.floridasupremecourt.org/decisions /probin/sc02-659.pdf.

244. See supra notes 233-35 and accompanying text.

245. Solove, supra note 236, at 1014.

246. See Nissenbaum, supra note 234 , at 43 ("We should not expect social norms, including informational norms, simply to melt away with the change of medium to digital electronic any more than from sound waves to light particles."). 
If third parties harvest information from court records, their use of the information may be unrelated to the purposes and context of allowing open access to court records. The focus of many online searches of public records is on an individual, not on evidence of how well the government functions or even the substance of a court case. ${ }^{247}$ The U.S. Supreme Court, in Reporters Committee, noted that the plaintiffs' interest was in information about a private citizen that came from agency documents, and that this information would "reveal[] little or nothing about an agency's own conduct." 248 Although the Court was interpreting FOIA, the argument also applies to information that is disconnected from court records. Separating information from original court records does not serve the purpose of allowing public access to the records.

\section{ANOTHER APPROACH-A FUNDAMENTAL SHIFT: FLORIDA'S EXPERIENCE}

For nearly twenty years courts have struggled to develop policies and rules governing public access to electronic records, even as development and implementation of electronic records systems have lagged. ${ }^{249}$ As implementation of e-filing systems gains momentum, the importance of these rules and policies increases. Florida courts have taken an approach that serves as a new model for considering how to address issues regarding access to electronic records.

In 2005, the Florida Supreme Court Committee on Privacy and Court Records noted: "Digital records create novel challenges, and so novel solutions are called for if the resolution of the tension inherent in a system that seeks to encourage public transparency while appropriately protecting privacy is to be resolved." 250 The "novel solution" Florida courts have adopted is to examine the nature of court records and the courts' core purpose and to devise rules to ensure those records serve that core purpose. ${ }^{251}$ Florida policy developers considered "whether the existing

247. See Solove, supra note 214, at 1197.

248. U.S. Dep't of Justice v. Reporters Comm. for Freedom of the Press, 489 U.S. 749, 773 (1989). For a discussion of the case, see supra notes 19-32 and accompanying text.

249. The Jennen Report was certainly correct in predicting that "courts will be faced with the challenge of analyzing and revising public access policies for some time." JENNEN, supra note 41, at 27.

250. FLORIDA 2005 REPORT, supra note 119, pt. 1, at 26.

251. See FLORIDA 2001 REPORT, supra note 243, at 32. 
framework of laws, policy and practice controlling access to court records, developed over decades prior to the emergence of electronic records" was adequate to address the goals of protecting privacy while still allowing public access in an electronic age..$^{252}$ Ultimately, the answer was that the framework had to change.253 The solution was to embed changes throughout the system rather than just add a special set of rules.

The adoption of policies regarding court records in Florida has been an ongoing process for more than ten years. ${ }^{254}$ The process in Florida started in 2000 when the Florida Supreme Court directed the Judicial Management Council255 to "examine issues relating to balancing privacy interests and the public's access to information in the context of the electronic access to court records."256 The Judicial Management Council issued its report in 2001. ${ }^{257}$ More recent developments continued in 2011,

252.

Id. at 31. The developers of Florida's policy worked with existing laws on public records access, including over one thousand exemptions. In re Amendments to Fla. Rule of Judicial Admin. 2.420 \& the Fla. Rules of Appellate Procedure, 31 So. 3d 756, 765 (Fla. 2010). They also had to consider Florida's separate constitutional provisions on public access to court records and privacy. FLA. ConST. art. I, $\$ 23$ ("Every natural person has the right to be let alone and free from governmental intrusion into the person's private life ...."); FLA. CONST. art. I, § 24(a) (ensuring a right "to inspect or copy any public record made or received in connection with the official business of any public body, officer, or employee of the state").

253. See FlORIDA 2001 REPORT, supra note 243, at 31-32.

254. One Florida Supreme Court justice expressed frustration with the long process. Bill Kaczor, Florida Supreme Court Justice Frustrated by Lack of Privacy Rules for Records, THE LEDGER.COM (Feb. 11, 2011), available at http://www.theledger.com /article/20110211/NEWS/102115051.

255. See Administrative Order at 2, In Re Judicial Mgmt. Council, No. AOSC06-62 (Fla. Oct. 30, 2006), available at http://www.floridasupremecourt.org/clerk ladminorders/2006/sc06-62.pdf. The Judicial Management Council is a judiciary branch advisory council. $I d$.

256. In re Report and Recommendations of the Judicial Mgmt. Council of Fla. on Privacy \& Elec. Access to Court Records, 832 So. 2d. 712, 713 (Fla. 2002) (footnote omitted). The court provided this direction in Objective IV D of Horizon 2002, The 2000-2002 Operational Plan for the Florida Judicial Branch, Florida Supreme Court (2000). Id. at 713 n.1.

257. FLORIDA 2001 REPORT, supra note 243. The Florida Supreme Court postponed its decision regarding the Judicial Management Council's recommendations until it could review the "report by the [legislative] Study Committee on Public Records." In re Report \& Recommendations of the Judicial Mgmt. Council, 832 So. 2d at 715. In 2002, the Florida legislature created the Study Committee on Public Records to address "issues of privacy and public access as they relate to . . . information contained in [public] court records." Act of June 5, 2002, ch. 2002-303, 2002 Fla. Laws 2385,2387 . The study committee produced its report in 2003. STUDY COMM. ON PUB. 
when the Florida Supreme Court adopted and implemented court rule amendments. ${ }^{258}$

The core changes in the Florida system originated in the 2005 Recommendations by the Study Committee on Privacy and Court Records. ${ }^{259}$ The committee viewed its task as creating "a blueprint for a comprehensive policy on court records."260 Rather than recommend policies and rules, ${ }^{261}$ the committee presented "a plan, or roadmap, to

ReCORDS, EXAMINATION OF THE EFFECTS OF ADVANCED TECHNOLOGIES ON PRIVACy AND Public ACCESS TO COURT RECORDS AND OfFICIAL RECORDS (2003) [hereinafter EXAMINATION OF THE EFFECTS OF ADVANCED TECHNOLOGIES], available at http://www.floridasupremecourt.org/pub_info/summaries/briefs/02/02-659/filed_0215-2003_studycommitteereport.pdf. The recommendations in that report were consistent with the 2001 Judicial Management Council recommendations. Amended Administrative Order at 3, In re Comm. on Privacy \& Court Records, No. AOSC04-4 (Fla. Feb. 12, 2004) [hereinafter Amended Administrative Order] (substituted for AOSC03-49, Nov. 25, 2003), available at http://www.floridasupremecourt.org/pub _info/documents/orders/02-13-2004_AmendedOrderPrivacyCourtRecords.pdf. Both noted the need to develop court rules and to restrict the posting of electronic records until appropriate policies were in place. Compare FLORIDA 2001 REPORT, supra note 243, at 9-10, with EXAMINATION OF THE EFFECTS OF ADVANCED TECHNOLOGIES, supra, at 8-9. The Florida Supreme Court, after reviewing the reports of the council and the study committee, adopted the recommendations of both groups and imposed a moratorium on the release of online records. Amended Administrative Order, supra, at 4,6 .

258. In re Implementation of Comm. on Privacy \& Court Records Recommendations-Amendments to the Fla. Rules of Civil Procedure, No. SC08-2443, 2011 WL 2566360, at*3 (Fla. June 30, 2011). This decision was revised and superseded by In re Implementation of Committee on Privacy and Court Records Recommendations. In re Implementation of Comm. on Privacy \& Court Records Recommendations, 78 So. 3d 1045 (Fla. 2011). The court noted that this adoption was "another necessary step in the [c]ourt's ongoing effort to provide the public with electronic access to nonconfidential court records." Id. at 1046 (footnote omitted).

259. FLORIDA 2005 REPORT, supra note 119, pts. 1-2. This report is available in seven parts at http://www.floridasupremecourt.org/pub_info/index.shtml\#Privacy under 2006 Court Order \& Limited Moratorium, Full Report. The parts are: Cover, Cover Letter, Part 1, Part 2, Part 3, Part 4, and Part 5. The parts are consecutively numbered. Parts 1 and 2 contain the report and recommendations of the committee. Id. pts. 1-2. Part 3 contains the comments of some members of the committee who had divergent views. Id. pt. 3. Part 4 is Appendix 1 (Legal Analyses) and Part 5 is Appendix 2 (Draft Rule Changes). Id. pts. 4-5.

260. Id. pt. 1, at 7. The committee viewed this policy as supporting the "move through the transition from a system of primarily paper records to one of primarily digital records." Id.

261. The Florida Supreme Court had directed the committee to recommend policies and rules. Amended Administrative Order, supra note 257, at 4 . The committee 
develop and effectuate a comprehensive set of policies to provide electronic access to court records while appropriately protecting privacy interests."262 The Florida Supreme Court characterized the report as presenting recommendations to address obstacles that prevented immediate implementation of remote electronic access and to develop "the necessary conditions for responsible electronic access."263

The committee noted that development of its recommendations "must include the engagement of many entities and individuals and cannot be accomplished quickly."264 The committee concluded that it was not possible at the time of the report to implement a system of remote access to electronic records. ${ }^{265}$ From 2005 onward, all work focused on implementation of the committee's recommendations. In 2006, the Florida Supreme Court issued an administrative order directing various actions to implement most of the committee's recommendations. ${ }^{266}$ Given that implementation of some recommendations would require additional work, the court issued a separate order establishing a Committee on Access to Court Records. ${ }^{267}$ This committee filed its final report in 2008. ${ }^{268}$ The

provided draft amendments to Florida Rule of Judicial Administration 2.051. FLORIDA 2005 REPORT, supra note 119, pt. 5, at 146.

262. FLORIDA 2005 REPORT, supra note 119, pt. 2, at 44. The committee presented twenty-four recommendations, many of which focused on specific issues with existing rules and policies. $I d$.

263. Administrative Order at 1 , In re Comm. On Access to Court Records, No. AOSC06-27 (Fla. Aug. 21, 2006) [hereinafter 2006 Administrative Order], available at http://www.floridasupremecourt.org/pub_info/documents/08-21-2006_AdminOrder AccessRecords.pdf.

264. FLORIDA 2005 REPORT, supra note 119, pt. 2, at 44.

265. Id. pt. 1 , at 33 .

266. Administrative Order at 1 , In re Implementation of Report \& Recommendations of the Comm. on Privacy \& Court Records, No. AOSC06-20 (Fla. June 30, 2006), available at http://www.floridasupremecourt.org/pub_info/OrderOn PrivacyCourtRecords.pdf. In a chart, the courts outlined the actions taken on the committee's recommendations. Id. at 18-23. One of the immediate actions was to impose a modified, limited moratorium on the release of electronic court records. Id. at 13. This action implemented Recommendation Five of the Florida 2005 Report. Id.; FLORIDA 2005 REPORT, supra note 119, at 50-51. The court provided details of the moratorium in a separate order. Administrative Order at 6, In re Interim Policy on Elec. Release of Court Records, No. AOSC06-21 (Fla. June 30, 2006) [hereinafter Interim Policy], available at http://www.floridasupremecourt.org/clerk/adminorders 12006/sc06-21.pdf. This order superseded the limited moratorium imposed by Amended Administrative Order, supra note 257.

267. In re Implementation of Report \& Recommendations of the Comm. on Privacy \& Court Records, No. AOSC06-20, at 11. The court also directed certain 
Florida Supreme Court first considered recommendations from this 2008 report in 2010, ${ }^{269}$ and it addressed additional recommendations in 2011.270 The adopted amendments, along with changes adopted in 2010, went into effect October 1, 2011. ${ }^{271}$

Many of the committee's recommendations were part of a strategy to "curtail, or minimize, the inclusion of personal information in court files that is unnecessary for purposes of adjudication and case management."272 The committee observed that a "court file is primarily a conduit and repository of information exchanged among parties and the court."273 The

existing groups, such as Florida Bar rules committees, to address some of the recommendations. For example, the court requested the Florida Bar rules committees "to review their respective bodies of rules and forms and to propose amendments to those rules and forms consistent with this recommendation." Id. at 15.

268. Fla. SUPREME COURT, COMM. ON ACCESS TO COURT RECORDS, Final REPORT AND RECOMMENDATIONS (2008), available at http://www.flcourts.org/gen _public/stratplan/bin/Access\%20Files/Full\%20Report.pdf. In 2007, the Committee on Access to Court Records had filed an interim report. Fla. SUPREME COURT, COMM. ON ACCESS TO COURT RECORDS, INTERIM PROGRESS REPORT AND RECOMMENDATIONS ON MODIFICATION TO INTERIM POLICY ON ELECTRONIC ACCESS TO COURT RECORDS (2007), available at http://www.floridasupremecourt.org/pub_info /documents/07-20-2007_InterimProgressReport.pdf. The primary consequence of this report was that the Florida Supreme Court revised its earlier moratorium order. See Administrative Order, In re Revised Interim Policy on Elec. Release of Court Records, No. AOSC07-49 (Fla. Sept. 7, 2007), available at http://www.floridasupremecourt.org /pub_info/documents/09-07-2007_Interim_Policy.pdf. This order revised and superseded Interim Policy, supra note 266.

269. In re Amendments to Fla. Rule of Judicial Admin. 2.420 \& the Fla. Rules of Appellate Procedure, 31 So. 3d 756 (Fla. 2010). In the interim, the order that created the committee expired. The court directed the chair of the Florida Court Technology Division to form the Subcommittee on Access to Court Records essentially to represent the former committee as the court considered the recommendations of the 2008 report. See Administrative Order at 2-3, In re Fla. Courts Tech. Comm'n, Subcomm. on Access to Court Records, No. AOSC09-3 (Fla. Jan. 27, 2009), available at http://www.floridasupremecourt.org/clerk/adminorders/2009/AOSC09-3.pdf.

270. In re Implementation of Comm. on Privacy \& Court Records Recommendations, 78 So. 3d 1045 (Fla. 2011).

271. Id. at 1055. For a discussion of the new rules, see Dan Bushell, A Primer on the New Privacy Rules for Florida Court Filings, FLA. APP. REV. (July 4, 2011), http://www.floridaappellatereview.com/florida-supreme-court/new-privacy-rules.

272. FLORIDA 2005 REPORT, supra note 119, pt. 1, at 23. See id. at 22-27 for more discussion.

273. Id. pt. 2, at 54. The Florida Supreme Court quoted this statement in its 2011 order implementing recommendations, which originated in the 2005 report. See Administrative Order at 4-5, In re Implementation of Report \& Recommendations of the Comm. on Privacy \& Court Records, No. AOSC06-20 (Fla. June 30, 2006), 
committee urged the Florida Supreme Court to consider that "a court file is not a public common, where anyone is free to post anything."274 Instead, the committee recommended addressing the inclusion and dissemination of personal information in court records at the source, requiring parties to "refrain from filing discovery information with the court until such time as it is properly filed for good cause."275 The Florida Committee on Privacy and Court Records focused on Florida's constitutionally based right of privacy. ${ }^{276}$ The committee interpreted this right as "operat[ing] to keep personal information out of government hands in the first place."277

A major focus of the recommendations the court adopted was the minimization of unnecessary personal information in court filings. The Florida Committee on Privacy and Court Records stated that these changes represented "a fundamental shift in the posture of courts in Florida regarding the very acceptance of filings." 278 The intent was to eliminate the filing of personal information "that is unnecessary for purposes of adjudication and case management." 279 In its 2005 Report, the Florida Committee on Privacy and Court Records observed that the recommended changes represented a shift from an "open" court file to a "controlled" file. ${ }^{280}$ The committee concluded that "the electronic release of court records cannot be achieved if court files remain open to receipt of unnecessary and immaterial personal information."281 Recommendation Seven of the 2005 Report specifically addressed this concern..$^{282}$

In response, the Florida Supreme Court approved amendments to court rules and forms to eliminate filing of extraneous personal information. ${ }^{283}$ It also adopted Rule of Judicial Administration 2.435,

available at http://www.floridasupremecourt.org/pub_info/OrderOnPrivacyCourt Records.pdf.

274. FLORIDA 2005 REPORT, supra note 119, pt. 1, at 25.

275. Id. at 27.

276. See id. at 27-37.

277. Id. at 27.

278. Id. at 25 .

$279 . \quad I d$. at 23.

$280 . \quad$ Id. at $25-26$.

281. Id. at 26.

282. Id. pt. 2, at 53 .

283. See In re Implementation of Comm. on Privacy \& Court Records Recommendations, 78 So. $3 d 1045$ (Fla. 2011). The rules amended were: the Florida Rules of Civil Procedure, the Florida Rules of Judicial Administration, the Florida Rules of Criminal Procedure, the Florida Probate Rules, the Florida Small Claims Rules, the Florida Rules of Appellate Procedure, and the Florida Family Law Rules of 
designed specifically to implement Recommendation Seven. ${ }^{284}$ This new rule identifies "categories of personal information that must not be filed or must be truncated or redacted before filing, and provides exceptions that allow for the filing of complete information in appropriate circumstances." 285 The court also approved Rule of Civil Procedure 1.280(f), which prohibits filing personal information generated in discovery unless it is filed for "good cause."286

The Committee on Privacy and Court Records also recognized a need to include some personal information in court documents. ${ }^{287}$ Other committee recommendations thus focused on examining exemptions and means of making information or documents confidential. ${ }^{28}$ In response, the Florida Supreme Court approved an amendment to Florida Rule of Judicial Administration $2.420^{289}$ to provide a means to identify and address

Procedure. See id. The amendments included changes to forms. See id. at 1055. A number of groups, including bar committees, contributed to the drafting of the changes. See id. at 1047.

284. Id. at 1048-52; FLA. R. JUD. ADMIN. 2.425 (limiting the types of sensitive information that can be filed with the court); see FLORIDA 2005 REPORT, supra note 119 , pt. 2, at 53 (recommending that the Florida Supreme Court modify "rules ... to avoid the filing of personal information which is not necessary for adjudication or case management"). The court also noted that the new rule is loosely based on Federal Rule of Civil Procedure 5.2 (Privacy Protections for Filings Made with the Court). In re Implementation, 78 So. $3 \mathrm{~d}$ at 1050.

285. In re Implementation, 78 So. 3d at 1049.

286. Id. at 1052-54; FLA. R. CIV. P. 1.280(f). This new provision implemented the Privacy Committee's Recommendation Ten. See Florida 2005 REPORT, supra note 119 , pt. 2 , at 56 . The committee's intent in recommending the creation of this rule of procedure was "to restrain parties who gain possession of information pursuant to compelled discovery from unnecessarily and gratuitously publishing such information into a court file." Id. at 27. The Report of the Civil Rules Committee, which recommended the rule, noted in its 2007 report that there were filings of discovery materials "for the purpose of embarrassment, intimidation, or mere perceived tactical advantage" rather than to further resolution of the case. See REPORT OF THE CIVIL Procedure Rules CommitTeE, IN RE REPORT AND RECOMMENDATIONS OF THE COMMITTEE ON PRIVACY AND COURT RECORDS 2 (2007), available at http://www.floridasupremecourt.org/decisions/probin/sc08-2443_AppendixG4.pdf.

287. See FLORIDA 2005 REPORT, supra note 119, pt. 1, at 27.

288. II. at 27,35 . In response to these recommendations, the Florida Supreme Court adopted revisions in court rules. See In re Amendments to Fla. Rule of Judicial Admin. 2.420 \& the Fla. Rules of Appellate Procedure, 31 So. 3d 756, 765 (Fla. 2010).

289. FlA. R. JUD. ADMIN. 2.420. This rule had been designated Rule 2.051, and was renumbered in a reorganization of the rules in 2006. See In re Amendments to the Fla. Rules of Judicial Admin.-Reorganization of the Rules, 939 So. 2d. 966, 100510 (Fla. 2006) (per curiam). 
confidential information in court documents. ${ }^{290}$ The amendment included a provision that provided requirements for filers to identify confidential information. ${ }^{291}$ The court explained that Rule 2.425 provides protection for information being filed, while Rule 2.420 provides procedures for determining the confidentiality of information after it has been filed. ${ }^{292}$ The result was a comprehensive overhaul of court filing rules and systems that minimized the information going into records and provided protections for the remaining necessary information.

\section{CONCLUSION}

For nearly twenty years, courts have struggled to develop policies and rules to govern public access to electronic records. As implementation of efiling systems gains momentum, determining how to address public access to electronic court records will remain an ongoing challenge. Approaches such as those described in the CCJ/COSCA Guidelines (e.g., limiting access and redaction) are still a starting point for discussion. These approaches, however, offer only transitory resolution.

The more comprehensive approach, as seen in Florida, focuses on embedding changes throughout the system, rather than merely creating a special set of rules in addition to existing filing rules. Not placing personal information in public records eliminates later inappropriate exposure. This approach requires examining all existing court filing rules and requirements, and understanding their purposes. Many courts have not considered the need to rethink the nature and purpose of filings. ${ }^{293}$ The core purpose of court documents is to facilitate resolution of disputes, and that purpose should define the extent of public access to information. The ultimate focus finally turns to the manner in which the very content of court records furthers the main purpose of the courts. As Professor Arthur Miller wrote: "[P]ublic access to information produced in litigation has

290.

See In re Amendments to Fla. Rule of Judicial Admin. 2.420, 31 So. 3d at 762. The amendment included a clarification of the public record exemptions that are appropriate under the rule. See id. at 763-65. The adoption of this amendment addressed Recommendation Two (Scope of Confidentiality), Recommendation Thirteen (Confidential Information), Recommendation Sixteen (Unsealing of Records), and Recommendation Seventeen (Responsibility of Filer) of the committee's 2005 recommendations. See id. at 759 n.9, 762-67.

291.

See id. at 765 .

292. Id. at 766.

293. See Anderson, supra note 33, at 11 (noting that due to the "existence of practical obscurity and limited access to court information," courts have given little consideration to what is in a court file, how it is accessed, or how it is used). 
always been a secondary benefit-a side effect—of civil adjudication. If public access assumes an importance on a par with the system's concern for resolving disputes among the litigants, the courts [would be] diverted from their primary mission." 294 While public access to court records is a fundamental right, courts must consider how access to such records actually serves the goal of resolving disputes. Examining and revising rules governing the nature of court filings is a time-consuming process that will result in a fundamental shift in "the way our courts conduct business and interact with the public."295 This shift is nevertheless necessary to achieve a satisfactory accommodation of the competing goals of public access to court records and protection of private information.

294. Arthur R. Miller, Confidentiality, Protective Orders, and Public Access to the Courts, 105 HARV. L. REV. 427, 431 (1991).

295. FLORIDA 2005 REPORT, supra note 119, at 44. 